\title{
FACTORS AFFECTING THE UTILIZATION OF 'POOR-QUALITY' FORAGES BY RUMINANTS PARTICULARLY UNDER TROPICAL CONDITIONS
}

\author{
R. A. LENG
}

Department of Biochemistry, Microbiology and Nutrition, University of New England, Armidale, NSW 2351, Australia

\section{CONTENTS}

INTRODUCTION . . . . . . . . . . . . . . . . . . 278

CHARACTERIZATION OF LOW-QUALITY FORAGES . . . . . . . 278

CHEMICAL COMPOSITION OF LOW-QUALITY FORAGES . . . . 279

BASIC CONCEPTS FOR ENSURING A BALANCED NUTRITION FOR RUMINANTS ON FORAGE-BASED DIETS . . . . . . . . . . $\quad$. 279

OPTIMIZING MICROBIAL GROWTH IN THERUMEN . . . . . . 280

MINERAL REQUIREMENTS OF RUMEN MICROBES . . . . . . . . . $\quad 280$

Requirements for sulphur . . . . . . . . . . . . . . . . 280

Requirements for phosphorus . . . . . . . . . . . . . . 280

Requirements for magnesium . . . . . . . . . . . . . . . . 281

Requirements for ammonia . . . . . . . . . . . . . 281

Timing of urea supplements and the ratio of sugars and starches to fibre in a

diet . . . . . . . . . . . . . . . 281

REQUIREMENTS FOR AMINO ACIDS/PEPTIDES BY RUMEN ORGANISMS : 283

MANIPULATING THE EFFICIENCY OF FERMENTATIVE DIGESTION. 285

THE ROLES OF SMALL AMOUNTS OF FRESH FORAGE IN STRAW-BASED

DIETS .

ELIMINATION OF RUMEN PROTOZOA AND PRESERVATION OF THE FAUNA-

FREE STATE .

ENSURING AN EFFICIENT METABOLISM IN THE ANIMAL . . . 288

FACTORS INFLUENCING EFFICIENCY OF FEED UTILIZATION . . . . $\quad 288$

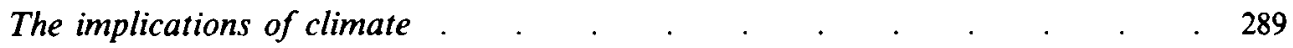

CLIMATE, SUPPLEMENTATION AND INTAKE OF LOW-QUALITY FORAGES . 291

EFFICIENCY OF FEED UTILIZATION AND ACETATE AVAILABILITY

TO RUMINANTS .

METABOLIZABLE ENERGY AS AN INDICATOR OF FEED QUALITY

OF LOW-DIGESTIBILITY FORAGES . . . . . . . . . . 294

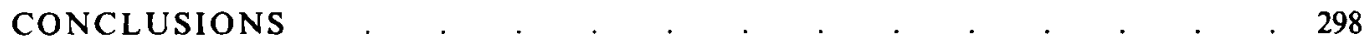

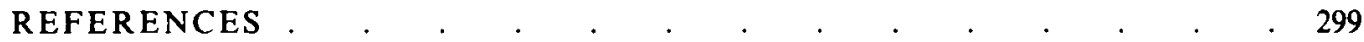




\section{INTRODUCTION}

The efficiency of utilization of 'low-quality' roughages by ruminants for productive purposes is altered by numerous factors which are associated with the feed or the animal. These include:

(1) the availability of microbial nutrients in the feed to support an efficient microbial growth, and a high rate and extent of digestion in the rumen which in turn optimizes intake;

(2) the ratio of soluble cell components to refractory cell wall carbohydrates in the forage. This ratio markedly affects the population density-mix of the major microorganisms in the rumen (e.g. bacteria, fungi and protozoa);

(3) the physiological state and previous dietary and health history of the animal which determines the quantitative demand for and balance of nutrients required;

(4) the thermal environment which determines the requirements for substrate oxidation for maintenance of body temperature and alters the balance of nutrients available for anabolic functions;

(5) the chemical and physical characteristics of forage which determine the proportion of feed digested by microbial fermentation and the dietary nutrients that escape rumen fermentation and are available for digestion and absorption in the intestines.

Under laboratory conditions many of the factors can be isolated and studied in detail, but few studies have attempted to elucidate simultaneously the interactions of the many factors that result in the efficiency of end-product utilization by the animal. Often feeding trials done in one location have given results that contradict those found in another. Much time and effort has been wasted attempting to disprove theses developed from data acquired under one set of conditions which cannot be repeated and are often unbelievable under another set of conditions.

In this presentation it has been assumed that research results reported in the literature are rarely erroneous, but it is the varying effects and interactions of differing conditions which result in often disparate conclusions. An attempt is made to explain some of the major differences between apparently conflicting results.

The absorption of nutrients from the digestive tract in quantities closely approximating the demand for specific physiological conditions is considered to override a large number of other factors and to determine the efficiency with which a ruminant uses its feed for production.

Central to the arguments is the concept that different balances of nutrients are required for animals under differing physiological, management and climatic conditions.

The usefulness of the concept of metabolizable energy (ME), in real world situations, as an index of the feeding value of forage is questioned.

\section{CHARACTERIZATION OF LOW-QUALITY FORAGES}

Low-quality forages are defined here as those forages which are less than $55 \%$ digestible and are deficient in true protein (say less than $80 \mathrm{~g}$ crude protein (nitrogen $\times 6.25 ; \mathrm{CP}) / \mathrm{kg}$ ) and low in soluble sugars and starches (usually less than $100 \mathrm{~g} / \mathrm{kg}$ ).

Low-quality forages are not used as the basis of diets in most temperate countries, but in tropical and subtropical countries often comprise practically the whole diet of ruminants either grazing or fed under subsistence conditions. In these countries, which are mostly in the tropics and subtropics, crop residues are a major component of a diet for large ruminants for a considerable part of or throughout the year (see Jackson, 1981). The present review therefore examines the factors affecting the utilization of low-digestibility 
forages with some emphasis on straw or tropical pasture fed to large ruminants under tropical conditions as these are the forage resources of most significance.

\section{CHEMICAL COMPOSITION OF LOW-QUALITY FORAGES}

In the literature concerned with the nutritional value of forages, considerable emphasis is placed on the crude chemical composition of the forage. Although analyses that indicate cell solubles and cell-wall materials are highly useful for studying the fermentative characteristics of a forage, they bear little relationship to its feeding value to the animal (see p. 295).

In the present review the overriding effects of a balanced nutrient approach to feeding are emphasized. It is suggested that, in most production systems for ruminants based on a poor-quality forage, it is the balance of those nutrients which provide the major building blocks for tissue synthesis and milk production that should be the primary concern. With most forages, the efficiency of feed utilization is the major determinant of the production levels achieved.

Recent evaluation of findings from studies in tropical countries has indicated that medium to high levels of production at very high feed conversion efficiencies can be achieved by ruminants on poor-quality forages adequately supplemented with critical nutrients (for review, see Preston \& Leng, 1987). Of more importance is that the efficiency of utilization of straw or straw-based diets with an ME:dry-matter ratio (M/D) of 5.5-8.0 appropriately supplemented can be higher than that of grain-based diets (M/D 12-14) (Leng, 1990). This suggests that the efficiency of utilization of ME of a forage can often be markedly improved by supplementation.

\section{BASIC CONCEPTS FOR ENSURING A BALANCED NUTRITION FOR RUMINANTS ON FORAGE-BASED DIETS}

The priority for improving the utilization of a low-digestibility forage by ruminants is to optimize the availability of nutrients from fermentative digestion by:

(1) ensuring that there are no deficiencies of microbial nutrients in the rumen and, therefore, the microbes in the rumen grow efficiently and, through fermentative activity, extract the maximum possible amounts of carbohydrate from the forage (i.e. the production rates and ratio of microbial cells to volatile fatty acids (VFA) produced is high);

(2) ensuring that the microbial cells (which provide most of the protein to the animal) synthesized in the rumen are not lysed and fermented in the rumen but are available for digestion and absorption as amino acids from the intestines.

It is also necessary to optimize the efficiency of utilization of the nutrients that arise from fermentative and intestinal digestion by supplementing with critical nutrients that escape or bypass rumen fermentation. This is to augment and balance the nutrients absorbed to provide sufficient for maintenance of homeostasis, maintenance of body temperature, exercise (or work), and any particular physiological or productive function.

In any one location, therefore, supplementation strategies will need to vary according to climate, management and production targets. 


\title{
OPTIMIZING MICROBIAL GROWTH IN THE RUMEN
}

\author{
MINERAL REQUIREMENTS OF RUMEN MICROBES
}

The rumen microbes have specific requirements for both macro- and micro-minerals to meet the needs of structural components of cells and for components of enzymes and cofactors. Little is known about the requirements of the microbial milieu for trace elements and as a 'rule of thumb' it is accepted that if the animal is not deficient then it is unlikely that the rumen microbes will be deficient. Rumen microbes have capabilities to extract and concentrate essential minerals; for example, recent studies have shown that cobalt at low rumen concentrations is rapidly taken up and concentrated by one species of bacteria (P. Costigan and R. Gerdes, personal communication).

As Suttle (1987) has so aptly put the situation, it will rarely be possible to approach a suspected deficiency situation with a table of minor nutrient requirements or biochemical criteria in the hand, and define a scale of the animal health (microbial health) problems. In practice, either no mineral supplements are used or a 'shot gun' mixture is given as salt licks (McDowell et al. 1984) or as molasses (which is concentrated plant juice rich in minerals) suitably fortified with minerals (Kunju, 1986). However, there is more known about the requirements of microbes for sulphur, phosphorus, magnesium and ammonia (Durand $\&$ Komisarczuk, 1988).

As with any deficiency of a nutrient, the likely scenario of a mineral deficiency for rumen organisms is first a reduced growth efficiency of microbes (lowered ratio of cells to VFA produced) with or without a decrease in digestibility. As the deficiencies become more extreme the digestibility of forage must decrease along with the decrease in microbial pool size and it is only then that feed intake will decrease. Correction of the deficiency will obviously have the reverse effects.

\section{Requirements for sulphur}

$\mathrm{S}$ is critical in the rumen for the synthesis of $\mathrm{S}$-amino acids for microbial protein synthesis. A critical level in the rumen is $1 \mu \mathrm{g} / \mathrm{ml}$ (Bray \& Till, 1975). Lower levels than this are likely to deplete the size of the microbial pool, eventually decreasing digestibility in addition to lowering the protein:energy $(\mathrm{P}: \mathrm{E})$ ratio in the nutrients absorbed. The rumen fungi appear to be particularly dependent on $\mathrm{S}$ and grow only at low rates where plant materials are low in S (see Gordon \& Phillips, 1989).

There is an absolute requirement for $\mathrm{S}$ and this is unrelated to CP content of a diet. In a $\mathrm{S}$ deficiency state, copper toxicity can result, particularly in fauna-free ruminants (Ivan, 1989; Hegarty et al. 1989).

$\mathrm{S}$ deficiency in ruminants is rarely detected in temperate industrialized countries, partly perhaps as acid rain ensures a high level of $S$ in forages (see Kandylis, 1984). S deficiency of livestock, however, may be widespread in the tropics because of high rainfall and the highly soluble nature of most natural $\mathrm{S}$ salts in soil.

\section{Requirements for phosphorus}

$P$ deficiency is often widespread in tropical countries (see McDowell et al. 1984) and P supplementation for the animal and the microbes is essential. Most protein meals or grain by-products are high in $P(5-10 \mathrm{~g} / \mathrm{kg})$ and supplements of proteins often correct such a deficiency. Undoubtedly during long periods of $\mathbf{P}$ deficiency this mineral may become deficient in the rumen, and will reduce microbial growth efficiency and at times digestibility and intake of forage (see Durand et al. 1986); however, where P supplements are given 
salivary $P$ secretion is often higher than dietary $P$ supply (see Smith, 1984). Where a protein meal is used to supplement a low-quality straw-based diet there is little likelihood of a $\mathbf{P}$ deficiency in the rumen.

\section{Requirements for magnesium}

$\mathrm{Mg}$ is often deficient in young grass, tropical forage, straw and other low-quality forages and a deficiency of $\mathrm{Mg}$ can reduce the digestibility and intake of a forage (see Wilson \& Minson, 1980). As $\mathrm{Mg}$ is essential for all rumen micro-organisms and particularly for cellulolytic microbes (Pettipher \& Latham, 1979), Mg sufficiency is a precondition for the optimal utilization of low-quality forages. $\mathrm{Mg}$ is not likely ever to be deficient in isolation and 'shot gun' mixtures are often the best approach to correct such a deficiency.

\section{Requirements for ammonia}

Ensuring adequate $\mathrm{NH}_{3}-\mathrm{N}$ in the rumen to supply the majority of $\mathrm{N}$ for microbial growth is the first priority in optimizing fermentative digestion of forage. Satter \& Slyter (1974) suggested that $50.80 \mathrm{mg} \mathrm{NH}_{3}-\mathrm{N} / 1$ rumen fluid was the optimum for maximizing microbial growth yield and this has been widely accepted. However, recent studies from two laboratories in Australia have indicated that the minimum level of rumen fluid ammonia for optimum voluntary intake of low- $\mathrm{N}$, low-digestibility forage by cattle is about $200 \mathrm{mg} \mathrm{NH}_{3}-\mathrm{N} / \mathrm{l}$ even though the digestibility of the forage (in nylon bags) was optimized below $100 \mathrm{mg} \mathrm{NH}_{3}-\mathrm{N} / 1$ (Krebs \& Leng, 1984; Boniface et al. 1986; Perdok et al. 1988).

The effects of increasing rumen fluid ammonia by infusion of urea into the rumen of steers on the intake of rice straw and its digestibility in nylon bags in the rumen are shown in Fig. 1.

Forage intake is related to the rate and potential digestibility of a forage (see Minson, 1982), and although no increase in straw digestibility was apparent above $100 \mathrm{mg} \mathrm{NH}_{3}$ $\mathrm{N} / \mathrm{l}$, this may have been due to the crudity of the nylon bag method (Perdok et al. 1988). If there was an increase in the microbial cells:VFA available from fermentative digestion, as $\mathrm{NH}_{3}-\mathrm{N}$ levels increased up to $200 \mathrm{mg} / \mathrm{l}$ (i.e. an improved bacterial growth efficiency or a decreased lysis of microbial cells in the rumen), this could be the stimulus for improved voluntary feed intake. This may be particularly pertinent in warm climates where the ratio of microbial protein to VFA produced is critical in determining the basal heat production of the animal (see p. 289).

The level of ammonia needed is almost certainly dependent on the $\mathrm{pH}$ of the rumen contents and, therefore, the relative $\mathrm{NH}_{3}: \mathrm{NH}_{4}{ }^{+}$ratio (see Smith, 1989). The $\mathrm{pH}$ of the rumen is consistently high $(6 \cdot 5-7 \cdot 0)$ where no concentrate is fed with poor-quality forages (which, by definition, are low in soluble sugars and starches). However, as $\mathrm{pH}$ decreases with grain additions to the diet, the level of ammonia needed may be somewhat lower than that reported by Boniface et al. (1986) and Perdok et al. (1988).

\section{Timing of urea supplements and the ratio of sugars and starches to fibre in a diet}

The effects of starch supplementation in a forage-based diet on fibre fermentation in the rumen have been well categorized (Ørskov \& Fraser, 1975). In general, with increasing grain in forage-based diets, the digestibility of the latter is reduced by both a specific (drop in $\mathrm{pH}$ ) and non-specific effect (carbohydrate or starch effect) on the growth of cellulolytic organisms.

Cattle in poor condition fed on low-quality forages are often diagnosed as "energy deficient ' and it is often recommended to feed a more-energy-dense supplement (e.g. grain). However, as is discussed later, the 'energy deficiency' is most probably related to inefficient 

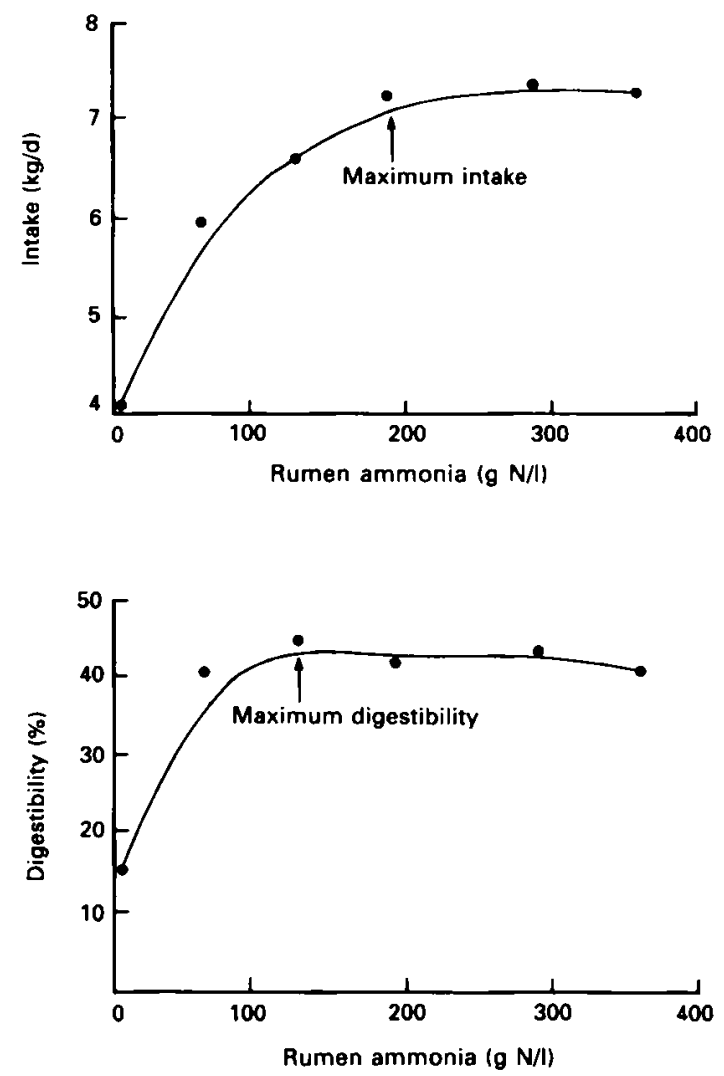

Fig. 1. The effects of the concentration of ammonia in the rumen on the intake and digestibility (measured in nylon bags in the rumen) of straw by cattle. The ammonia levels were adjusted by infusing urea into the rumen (Perdok et al. 1988).

utilization of nutrients because of the imbalance in the substrates absorbed. Grain supplementation of forage-based diets is contra-indicated because it depresses digestibility and reduces forage intake and because it does not correct the imbalances of nutrients available to an animal (i.e. the ratio of microbial cells to VFA produced is not significantly altered). However, where diets of low-quality forages and grains are balanced, both at the level of the rumen and the animal, significant production responses can be achieved (Lee et al. 1987).

The influence of sugar in the diet on fibre degradation is less well understood. Most forages are a mixture of sugar-fibre, which varies in pastures, according to temperature/sunshine hours, night temperatures, and soil moisture conditions and in crop residues according to harvesting conditions and length and conditions of storage. In general, tropical grasses are lower in sugars than temperate grasses (see Minson, 1982). Sugar cane is relatively low in sugar in the growing season but it represents $30 \%$ of the total stem dry matter when it is mature. Rice straw collected soon after harvest of the grain may be $55 \%$ digestible because of a high sugar level and will drop to $40-45 \%$ during storage as these sugars are lost.

Sugar is fermented almost instantaneously when it enters the rumen, whereas the fermentation rate of fibre may reach a peak at some $4-6 \mathrm{~h}$ post ingestion of a roughage (Annison \& Lewis, 1959). 
Table 1. The influence of the crude protein (nitrogen $\times 6.25$ ) content of the basal diet of poorquality forages (straw + concentrate) given to lactating buffaloes on the voluntary intake of a block lick based on molasses-urea (Leng \& Kunju, 1990)

\begin{tabular}{ccccc}
\hline \hline Group no. & $\begin{array}{c}\text { Diet } \mathrm{N} \\
\text { content } \\
(\mathrm{g} \mathrm{N})\end{array}$ & $\begin{array}{c}\text { Intake of } \\
\text { block lick } \\
(\mathrm{g} / \mathrm{d})\end{array}$ & $\begin{array}{c}\text { Milk } \\
\text { produced } \\
\text { FCM }(\mathrm{kg} / \mathrm{d})\end{array}$ & $\begin{array}{c}\text { Live wt } \\
\text { changes } \\
(\mathrm{g} / \mathrm{d})\end{array}$ \\
\hline 1 & 0 & 586 & $4 \cdot 3$ & -357 \\
2 & 30 & 256 & $5 \cdot 7$ & -455 \\
3 & 83 & 293 & $6 \cdot 3$ & +276 \\
4 & 111 & 173 & $6 \cdot 1$ & +89 \\
\hline
\end{tabular}

FCM, fat-corrected milk.

Supplements must provide adequate levels of ammonia in the rumen for continuous growth of both fibrolytic and saccharolytic organisms. The only satisfactory approach to meeting these changing requirements for ammonia is to provide ammonia continuously. One way of doing this is to provide salt-urea or molasses-urea licks and allow the animal to take this as needed. There are indications that cattle and buffaloes given continuous access to multi-nutrient blocks based on molasses-urea are able to control fairly closely their intake of urea. Once buffaloes were accustomed to molasses-urea blocks they adjusted their intake according to the $\mathrm{N}$ content of the basal diet (Table 1). Lambs given wheat straw and molasses-urea blocks also had similar abilities and consistently maintained their rumen $\mathrm{NH}_{3}-\mathrm{N}$ levels above $200 \mathrm{mg} / \mathrm{l}$ (Sudana \& Leng, 1986).

\section{REQUIREMENTS FOR AMINO ACIDS/PEPTIDES BY RUMEN ORGANISMS}

There has been considerable controversy concerning the requirements for peptides/amino acids by rumen microbes for efficient growth. Maeng $e$ t al. (1976) suggested that microbial growth efficiency was improved in washed rumen microbes by including amino acids as well as urea in the incubation medium. These results supported suggestions that protein added to poor-quality diets increased microbial protein synthesis and protein flow from the rumen (Hume, 1970; Ben-Ghedalia \& Yosef, 1989). Recently Argyle \& Baidwin (1989) supported the suggestion that increased microbial growth efficiencies resulted when amino acids and peptides provided a proportion of the $\mathrm{N}$ available in an incubation medium containing rumen organisms. Microbial growth efficiency was optimized at $10 \mathrm{mg} / \mathrm{l}$ of a complete amino acid mixture or when a solution of trypticase was added to cultures given a rather complex mixture of carbohydrates. These studies illustrated a quantitative need by rumen microbes for all amino acids and not a response to specific growth-limiting amino acids.

There have been a number of studies reported in vivo which appear to have indicated no apparent requirement for amino acids for efficient growth of rumen organisms (see Leng \& Nolan, 1984). The results of studies by Maeng et al. (1989) may explain some of these contradictory results. The studies of these researchers indicated that rumen microbes growing on different carbohydrate substrates have requirements for different $\mathrm{N}$ substrates; cellulolytic organisms may not require amino acids to the same extent as organisms growing on starch or sugar as the major substrate. The values shown in Table 2 indicate a marked effect of both dilution rate and the presence of peptides/amino acids on microbial growth efficiency. For microbes utilizing sugars or starches there was an apparent high requirement for preformed amino acids/peptides but this was not apparent for cellulolytic 
Table 2. The effects of urea and amino acids on the efficiency of growth of rumen microbes in continuous culture (after Maeng et al. 1989)

(The values are given as $\mathrm{g}$ microbial dry matter/mol carbohydrate disappearing.)

\begin{tabular}{|c|c|c|c|c|c|}
\hline \multicolumn{2}{|c|}{ Substrate } & \multicolumn{3}{|c|}{ Dilution rate (turnover/d) } & \multirow{2}{*}{$\begin{array}{c}\text { Mean relative } \\
\text { growth rate } \\
(\%)\end{array}$} \\
\hline Carbohydrate & Nitrogen & 0.51 & $1 \cdot 2$ & $2 \cdot 4$ & \\
\hline Glucose & $\begin{array}{l}\text { Urea } \\
\text { Urea-amino acids } \\
(75: 25, w / w)\end{array}$ & $\begin{array}{l}23 \\
28\end{array}$ & $\begin{array}{l}26 \\
38\end{array}$ & $\begin{array}{l}29 \\
39\end{array}$ & $\begin{array}{l}100 \\
143\end{array}$ \\
\hline Starch & $\begin{array}{l}\text { Urea } \\
\text { Urea-amino acids } \\
(75: 25, w / w)\end{array}$ & $\begin{array}{l}25 \\
30\end{array}$ & $\begin{array}{l}23 \\
33\end{array}$ & $\begin{array}{l}24 \\
36\end{array}$ & $\begin{array}{l}100 \\
137\end{array}$ \\
\hline Cellulose & $\begin{array}{l}\text { Urea } \\
\text { Urea-amino acids } \\
(75: 25, w / w)\end{array}$ & $\begin{array}{l}28 \\
31\end{array}$ & $\begin{array}{l}16 \\
19\end{array}$ & $\begin{array}{l}15 \\
14\end{array}$ & $\begin{array}{l}100 \\
106\end{array}$ \\
\hline
\end{tabular}

organisms. A surprising finding is that optimum microbial growth efficiency on cellulose substrate occurred at low dilution rates and was decreased as these approached 'normal' rumen turnover rates.

An increase in efficiency of microbial growth on fibrous carbohydrates with decreasing dilution rate as shown by Maeng et al. (1989) may be advantageous to ruminants given lowquality forages that must be retained in the rumen for a considerable period to allow digestibility to be optimized. At the same time the improved ratio of cells:VFA yielded along with the increased availability of the total nutrients are both advantageous. Such a mechanism would advantage an animal with a comparatively slower turnover rate of rumen contents (i.e. buffalo $v$. cow or goat $v$. sheep, see Devendra, 1990) - where a manipulation of the rumen ecosystem reduces turnover rate of the rumen digesta (e.g. supplementation with monensin (Chalupa, 1980) or in the fauna-free $v$. faunated animal (Bird \& Leng, 1985) or in animals in hot climates $v$. cold-stressed animals (Young, 1983)).

On fibrous diets also containing grain, peptide and amino acid may have an influence on fibre digestion in the rumen of cattle (see McAllan \& Smith, 1983; McAllan \& Griffith, 1987; Smith et al. 1987) and may also increase microbial growth efficiency (McAllan et al. 1988). But a search of the literature showed that little or no evidence was available on the need for peptides and amino acids by rumen organisms utilizing only fibrous feeds in vivo (i.e. with no concentrate in the diet).

The organisms in the rumen that are largely responsible for the fermentation of cellulose (Ruminococcus albus, Ruminococcus flavefaciens and Fibrobacter succinogenes (previously called Bacteroides succinogenes)) appear to have minimal requirements for amino acids and grow on ammonia (Bryant \& Robinson, 1961 a, 1962; Allison et al. 1962; Hobson et al. 1988). Conversely, organisms important in starch hydrolysis (Butyrivibrio fibrisolvens, Bacteroides ruminicola, Selenomonas ruminantium, Streptococcus bovis and Ruminobacter (Bacteroides) amylophilus (Hobson et al. 1988)) readily incorporate amino acid-N and in many cases peptides (Bryant \& Robinson, 1961 a,b, 1962, 1963; Pittman et al. 1967; Hobson et al. 1968; Cotta \& Russell, 1982; Russell, 1983). Thus, the growth efficiency of the resident microbial population in the rumen of animals on forage-based diets is influenced by the level of starch in the diet and the soluble carbohydrate component of fibrous feed. 
Supplementation of sheep fed on a poor-quality forage with branched-chain VFA has been reported to increase the apparent flow of microbial-N to the duodenum (Kay \& Phillipson, 1964). The apparent stimulation of microbial growth with branched chain-VFA has also been shown to increase feed intake of sheep in some experiments (Helmsley \& Moir, 1963). This together with the suggested requirements for peptides/amino acids by rumen organisms (which on the basis of Maeng et al. (1989) must now be questioned) has tempted many scientists to account for the increased feed intake of ruminants that occurs, at times, on poor-quality forages by the presence of a relatively insoluble protein meal that slowly yields amino acids, peptides and branched-chain fatty acids to the rumen milieu (see Hunter, 1988; Silva \& Orskov, 1988). There is however no evidence of increased fibre digestibility with such supplementation on predominantly fibre-based diets (Hungate \& Dyer, 1956).

The previous discussion suggests to this author that the cellulolytic organisms are rarely if ever deficient in amino acids, peptides or branched-chain VFA in the rumen (see also Maeng et al. 1989). This is not to deny that these organisms may still need the peptides, amino acids and branched-chain fatty acids in 'catalytic' amounts but that they are rarely if ever at such low concentrations in rumen fluid as to bring about a deficiency.

\section{MANIPULATING THE EFFICIENCY OF FERMENTATIVE DIGESTION}

\section{THE ROLES OF SMALL AMOUNTS OF FRESH FORAGE IN STRAW- BASED DIETS}

Farmers in developing countries have generally recognized the benefits to cattle of adding a small amount of fresh green herbage to straw-based diets. These practices, which have evolved through observation, may have a number of beneficial effects, which include the supply of vitamin $\mathrm{A}$ and essential minerals and of ammonia and peptides/amino acids in an otherwise unsupplemented diet.

Recently it has been shown that where the supplemental forage in a straw-based diet given to sheep is of high digestibility, a boost to digestibility of the basal diet occurs even at relatively small levels of supplementation (Juul-Nielson, 1981; Ndlovu \& BuchananSmith, 1985; Silva \& Ørskov, 1988). The rate of digestibility of straw depends on the rate and extent of colonization of fibre and the biomass of adherent organisms (Cheng et al. 1990). It has always been assumed that colonization of fibre entering the rumen is from the free-floating pool of bacteria in the rumen. In studies in which ${ }^{15} \mathrm{NH}_{3}$ or ${ }^{35} \mathrm{SO}_{4}{ }^{35} \mathrm{SO}_{4}^{2-}$ were infused in the rumen to label the bacteria, when these organisms were transferred to the rumen of control sheep, little of the radioactivity became associated with fibre. This suggests that colonization of bacteria occurs from fibre to fibre without passing through the free-floating pool (Krebs et al. 1989).

If the suggestion by Krebs et al. (1989) is true, a further explanation for the beneficial effects of the incorporation of high-digestibility forage in an otherwise low-digestibilityforage diet could be that this exerts a large effect on digestibility by providing a highly colonized fibre source to 'seed' bacteria onto the less-digestible fibre. On the other hand, other influences cannot be ruled out. For example, in the studies of Silva \& Ørskov (1988) in the absence of an effect of supplemental forage on digestibility, the rumen $\mathrm{NH}_{3}$ levels were often not significantly below $200 \mathrm{mg} \mathrm{NH}_{3}-\mathrm{N} / \mathrm{l}$. Where increases in digestibility of the basal forage occurred to supplemental forage the $\mathrm{NH}_{3}$ levels in the rumen were significantly below $200 \mathrm{mg} \mathrm{N} / 1$ and the supplement apparently improved the concentration to above the critical level (Table 3). 
Table 3. The effects on the potential degradability ( $\mathrm{mg} / \mathrm{g}$ dry matter $(D M)$ ) of barley straw incubated in nylon bags in the rumens of sheep fed on untreated barley-straw diet with or without $150 \mathrm{~g} / \mathrm{d}$ of a supplement

(The straw was supplemented with a complete mineral mix (Silva \& Ørskov, 1988.)

\begin{tabular}{lccc}
\hline \hline Supplement & $\begin{array}{c}\text { Rumen fluid } \\
\text { ammonia } \\
\text { concentration } \\
(\mathrm{mg} / \mathrm{l})\end{array}$ & $\begin{array}{c}\text { Potential } \\
\text { degradability } \\
\text { of straw (Pd)* } \\
(\mathrm{mg} / \mathrm{g} \mathrm{DM})\end{array}$ & $\begin{array}{c}\text { Statistical } \\
\text { significance } \\
\text { of Pd: } P\end{array}$ \\
\hline Sugar-beet pulp & 226 & 546 & 0.05 \\
Nil & 158 & 515 & NS \\
Citrus pulp & 225 & 563 & \\
Nil & 210 & 573 & 0.05 \\
Dried grass & 217 & 531 & NS \\
Nil & 145 & 605 & \\
Soya-bean meal & 291 & 523 & NS \\
Nil & 186 & 527 & \\
Fish meal & 307 & 618 & 619 \\
Nil & 194 & & \\
\hline \hline
\end{tabular}

NS, not significant.

- Pd in nylon bags was estimated according to the equation of Ørskov \& McDonald (1979). The significance of the effect of forage supplement in each treatment is shown.

\section{ELIMINATION OF RUMEN PROTOZOA AND PRESERVATION OF THE FAUNA-FREE STATE}

The view has been put forward (quoted by Bird et al. 1989) that protozoa in the rumen can be regarded as a major parasite of ruminants, particularly when these animals are fed on diets low in true protein. This view has been contested by Ryle \& Orskov (1987), who supported their opinions using examples from the literature. These authors called for 'careful examination of supporting evidence before accepting the conclusions that improvements are obtained' (in fauna-free animals).

Because of the prominence given to the review of Ryle \& Ørskov (1987), some further relevant results are presented here which demonstrate the benefits of the fauna-free state on production of ruminants on fibrous diets or diets containing forage-sugar or forage-starch but low in protein.

In a recent international seminar it was acknowledged that the presence of protozoa in the rumen significantly decreases the amount of bacterial protein leaving the rumen and becoming available for digestion in the intestines (for recommendations see Nolan et al. 1989). In terms of the ratio of protein from microbes to VFA energy in the nutrients absorbed, this may change that ratio from $25 \mathrm{~g}$ microbial protein/MJ VFA in fauna-free ruminants to below $12-14 \mathrm{~g}$ microbial protein/MJ VFA in faunated ruminants.

The physiological research which has shown that there is an increased availability of microbial protein for digestion in fauna-free as compared with faunated ruminants (see Veira et al. 1983; Ushida et al. 1989) has supported applied research involving feeding trials with large numbers of animals (Bird \& Leng, 1978; Bird et al. 1979; Bird, 1989). In sheep on a sugar-fibre diet, increasing levels of fish meal in the diet (Fig. 2) increased wool growth 

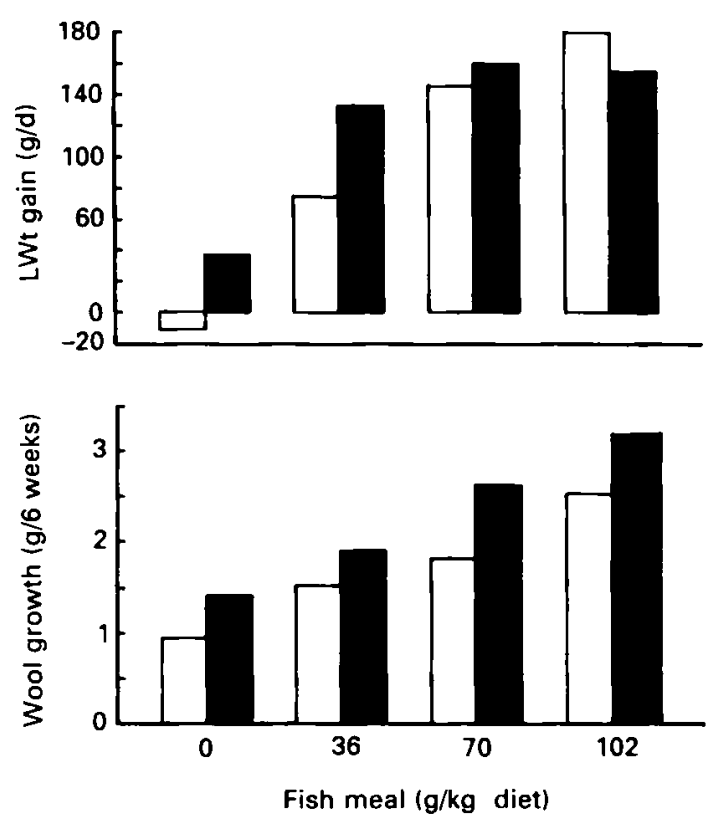

Fig. 2. Wool growth as measured on a mid-side patch and live-weight gain of faunated ( $\square$ ) and faunafree (ص) sheep given oaten chaff-sugar-based diets plus increasing levels of fish meal (Bird et al. 1979). Live-weight $(\mathrm{LWt})$ gain between faunated and unfaunated sheep was significantly different $(P<0.05)$ at the levels of 0 and 3.6 inclusion of fish meal in the diet. The standard error of the mean (SEM) of LWt gain was $11.1 \mathrm{~g} / \mathrm{d}$. For wool growth, the SEM was $0.15 \mathrm{~g} / 6$ weeks per patch and was significantly different $(P<0.01)$ for all levels of supplementation.

(which is responsive to the quantities of amino acids absorbed from the intestines; Reis \& Schinckel, 1961). At all levels of fish-meal supplementation wool growth was greater (Bird et al. 1979) in fauna-free as compared with faunated sheep. Fauna-free cattle on the same intake of a low-protein molasses-urea-based diet grew at a $43 \%$ greater rate than faunated cattle on the same feed intake. The improved production was, therefore, an effect of a higher efficiency of feed utilization (Bird \& Leng, 1978).

The discussion to follow, on the implications of environmental temperature/humidity for the nutrition of ruminants, will indicate why a major change in $P: E$ ratio in the nutrients absorbed (i.e. the major difference between faunated and fauna-free ruminants) will be more effective in improving ruminant production in the tropics as compared with temperate/cold countries. In tropical areas the available forages used to feed ruminants are generally lower in digestibility, lower in true protein and animals are rarely cold, but heat stress at times may be severe.

Increases in digestibility of fibrous feeds and increases in live-weight gain and wool growth have been observed when protozoa are absent from the rumen of sheep on strawbased diets (Soetanto, 1986; Romulo et al. 1989), including those supplemented with substantial quantities of grain and/or bypass protein (Forster \& Leng, 1989; Habib et al. 1989), but studies from other laboratories have not confirmed the increased digestibility (Jouany \& Ushida, 1990). A typical response in wool growth and live-weight gain to feeding both an insoluble-protein meal and maize to faunated and fauna-free sheep on straw-based diets is shown in Fig. 3.

These findings show the potential for improvement in ruminant productivity on lowquality forages by sustaining fauna-free animals (Bird, 1989). The surprising result has been 

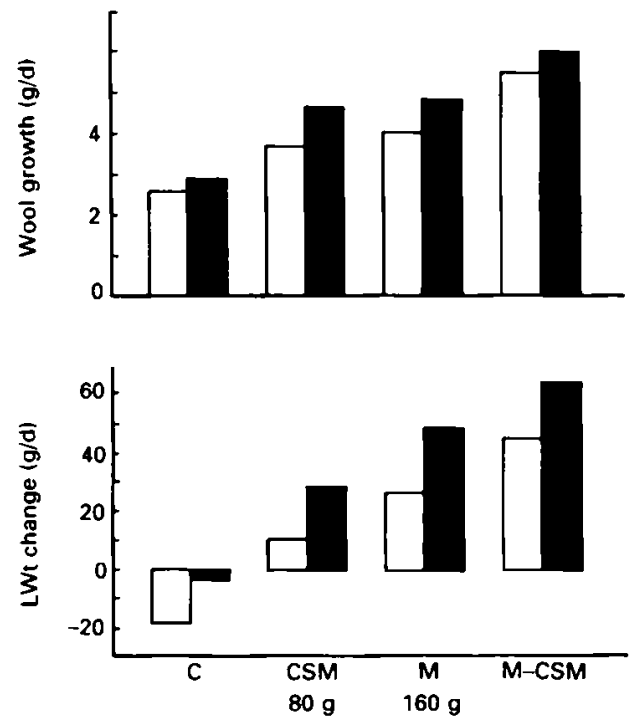

Fig. 3. Wool growth and live-weight (LWt) gain of faunated $(\square)$ and fauna-free ( $\square$ ) sheep given wheatstraw-based diets supplemented with maize $(M ; 160 \mathrm{~g} / \mathrm{d})$ and $/$ or cottonseed meal $(\mathrm{CSM} ; 80 \mathrm{~g} / \mathrm{d})$. The standard error of the mean (SEM) of the difference between faunated and unfaunated lambs for LWI gain was $6.5 \mathrm{~g} / \mathrm{d}$ and the differences were significant at $P<0.001$. For wool growth, SEM $=0.3 \mathrm{~g} / \mathrm{d}$ and the difference was significant at $P<0.001$.

that the protozoal density seems to have little effect, a low density being as detrimental as a relatively high density of protozoa in the rumen (Bird et al. 1990).

The major advantage of the unfaunated state will always be seen when the P:E ratio in the nutrients absorbed is low and where rumen microbial growth is not constrained by nutrient deficiencies. It is, therefore, not surprising that on high-quality feeds, high in true protein, responses to the unfaunated state are often not observed (for review, see Nolan $e t$ al. 1989). The difficulties of maintaining animals protozoa-free following treatment have also often resulted in confusing results where the effects of the surface-active agents are still apparent in the experimental period. Recent research with large numbers of sheep (forty per group) at pasture in the New England area have shown that over a 2-year period unfaunated sheep isolated from faunated sheep produced $1 \mathrm{~kg}$ more wool each year on average and were $4.5 \mathrm{~kg}$ heavier than the control sheep (S. H. Bird and R. A. Leng, unpublished results).

\section{ENSURING AN EFFICIENT METABOLISM IN THE ANIMAL}

\section{FACTORS INFLUENCING EFFICIENCY OF FEED UTILIZATION}

The efficiency with which absorbed nutrients are converted to ruminant products (live weight, milk, etc.) is dependent on precisely meeting the animal's requirements for individual nutrients required for the particular function (see Preston \& Leng, 1987). These, at times, are influenced by body condition as affected by previous health and nutritional history (see Leng, 1990), the demands for body temperature control (Blaxter, 1962) and the requirements for substrate oxidation for exercise (or work). Graham et al. (1959) (also, see Blaxter, 1962) showed that the quantitative oxidation of individual nutrients (largely fat) depended on the degree of heat/cold stress of the animal. 


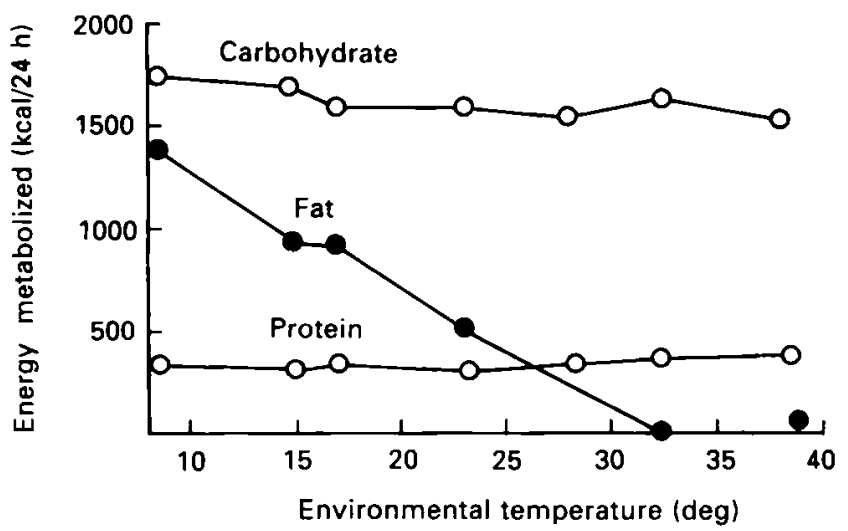

Fig. 4. Catabolism of nutrients by closely shorn sheep at varying environmental temperatures (humidity $50 \%$ ) (after Graham et al. 1959; Blaxter, 1962).

\section{The implications of climate}

Changes in the pattern of utilization of nutrients by sheep (with little or no wool for insulation) subjected to a range of temperatures is shown in Fig. 4. Calculations based on the respiratory quotient of sheep under cold stress indicated that the ruminant appears to oxidize fat for heat production when cold-stressed. The availability of such substrate (i.e. acetate, butyrate and long-chain fatty acids) for oxidation to meet energy requirements for product synthesis and maintenance can, therefore, be influenced by the requirements for heat generation to maintain body temperature. In the present review it is assumed that a cold-stressed animal will oxidize acetogenic substrate for heat production until 'surplus' acetogenic substrate is totally utilized, after which fat mobilization provides an extra source of metabolic fuel. Thus, the preferential oxidation of circulating acetate leaves a higher ratio of amino acids (and glucose) in the nutrients available for production than would be available to an animal in its zone of thermoneutrality. Conversely an animal that is not required to produce heat, above basal metabolism, will have more acetogenic substrates available for anabolic purposes.

The environment can, thus, alter the partitioning of nutrients into productive functions and affect the efficiencies of feed utilization. The design of supplements, to balance diets for ruminants, needs to account for the varying demands for nutrients brought about by the thermal environment of the animal.

It is recognized that cold stress in animals often increases voluntary feed intake and rumen turnover rate. And in this way it increases microbial cells moving to the lower tract, thus increasing the $\mathrm{P}: \mathrm{E}$ ratio in the nutrients available for maintenance or production (see Kennedy et al. 1986).

As an example of how environmental factors can change the nutrient balance available to ruminants for anabolism and maintenance, a model used previously to predict the relative availability of specific nutrients to a 'standard steer' (see Leng, 1982) has been modified to use with sheep and includes the effects of cold stress. The model is based on the sheep (closely shorn) used in the studies of Graham et al. (1959) which were fed on a daily basis 600,1200 or $1800 \mathrm{~g}$ dried-grass pellets and subjected to short periods at environmental temperatures ranging from $8-40^{\circ}$ at a relative humidity of $50 \%$.

The values in Table 4 indicate that the need to maintain body temperature may require a considerable proportion of the available acetogenic nutrients to be oxidized. In the absence of a cold stress considerably more of digestible nutrients (and in particular more 
Table 4. A theoretical assessment of the effects of environmental temperature on the balance of nutrients available for anabolism

(The example used is from Graham et al. (1959), in which closely shorn sheep were subjected to temperatures from 8 to $40^{\circ}$.)

\begin{tabular}{|c|c|c|c|}
\hline Ration (g dried grass/d) $\ldots$ & 600 & 1200 & 1800 \\
\hline Minimal heat production (MHP) & $5 \cdot 8$ & $8 \cdot 3$ & $10 \cdot 5$ \\
\hline Temperature at MHP (deg) & 40 & 33 & 24 \\
\hline $\begin{array}{l}\text { Metabolizable energy intake (MJ) at } \\
\text { MHP }\end{array}$ & $5 \cdot 1$ & $9 \cdot 8$ & $13 \cdot 7$ \\
\hline $\begin{array}{l}\text { Heat production required to combat } 5^{\circ} \\
\text { below critical temperature }(\mathrm{MJ})^{*}\end{array}$ & $2 \cdot 2$ & $2 \cdot 2$ & $2 \cdot 2$ \\
\hline \multicolumn{4}{|l|}{ Nutrients available $(\mathrm{MJ}) \dagger$ from: } \\
\hline Acetic acid & 1.9 & $3 \cdot 80$ & $4 \cdot 75$ \\
\hline Butyric acid & 0.27 & 0.54 & 0.74 \\
\hline Propionic acid (G) & 0.54 & 1.08 & 1.49 \\
\hline Total VFA (E) & $2 \cdot 71$ & $5 \cdot 42$ & 6.98 \\
\hline Microbial protein available $(\mathrm{g} / \mathrm{d})$ & 72 & 148 & 198 \\
\hline $\mathrm{P}: \mathrm{E}$ ratio $(\mathrm{g} / \mathrm{MJ}) \ddagger$ & $26: 1$ & $27: 1$ & $28: 1$ \\
\hline Available $P: E$ ratio $(\mathrm{g} / \mathrm{MJ}) \S$ & $118: 1$ & $45: 1$ & $40: 1$ \\
\hline$G: E$ ratio $(\mathrm{MJ} / \mathrm{MJ}) \|$ & 0.25 & $0 \cdot 24$ & $0 \cdot 27$ \\
\hline Available $\mathbf{G}$ : E ratio $\S$ & $7 \cdot 71$ & $0 \cdot 48$ & 0.43 \\
\hline
\end{tabular}

VFA, volatile fatty acids.

* The heat production for each degree lowering of environmental temperature below the critical temperature was assumed to increase by $0.44 \mathrm{MJ} / 24 \mathrm{~h}$ (Graham et al. 1959).

$\dagger$ The available nutrients are calculated assuming that all the digestible dry matter is digested in the rumen, that the rumen microbes have a $\mathrm{Y}_{\mathrm{ATP}} 14$ and that microbial cell synthesis and VFA production are stoichiometrically related as described by Leng (1982). No allowance was made for a possible increase in dilution rate with increasing feed intake.

$\ddagger$ Calculated microbial protein available (g) for digestion relative to VFA produced (MJ).

$\|$ Propionate (MJ): acetate plus butyrate (MJ) available; the glucogenic energy ratio (see Preston \& Leng, 1987).

$\S$ The available $P: E$ and $G: E$ ratios are defined as the nutrient ratios after the acetogenic nutrients have been used for body temperature control at $5^{\circ}$ below the critical temperature. They are calculated assuming that the energy for heat production arises from the oxidation of acetate and/or butyrate. Graham et al. (1959) showed fat was the major source of heat and that metabolism of glucogenic or aminogenic substrate is unaffected by cold stress whereas fat (acetogenic substrate) oxidation accounted for the heat produced.

acetogenic substrate) is available for maintenance and synthesis. If in thermoneutral conditions the acetogenic substrate cannot be utilized for synthesis of tissue component because of a low availability of essential amino acids and/or glucose (see Preston \& Leng, 1987), then acetate must be dissipated as heat. If the animal is able to oxidize the excess substrate but cannot dissipate the heat generated because environmental temperature and humidity are high, then it could allow its body temperature to increase to some extent, but eventually it must reduce its feed intake. If the animal's body temperature rises, metabolic rate increases through the oxidation of protein (Blaxter, 1962), which may have implications for protein requirements of ruminants in the tropics and differential responses to supplementation in the tropics as compared with temperate areas.

The temperature/humidity at which ruminants are cold-stressed depends greatly on the level of feed intake, the insulation provided by the hair or wool coat and the environmental conditions prevailing, e.g. wind, rain and availability of shelter. Thus, the environmental temperatures at which minimum extra heat production to combat the cold stress occurs will probably move through a range of from about 10 to $40^{\circ}$. 


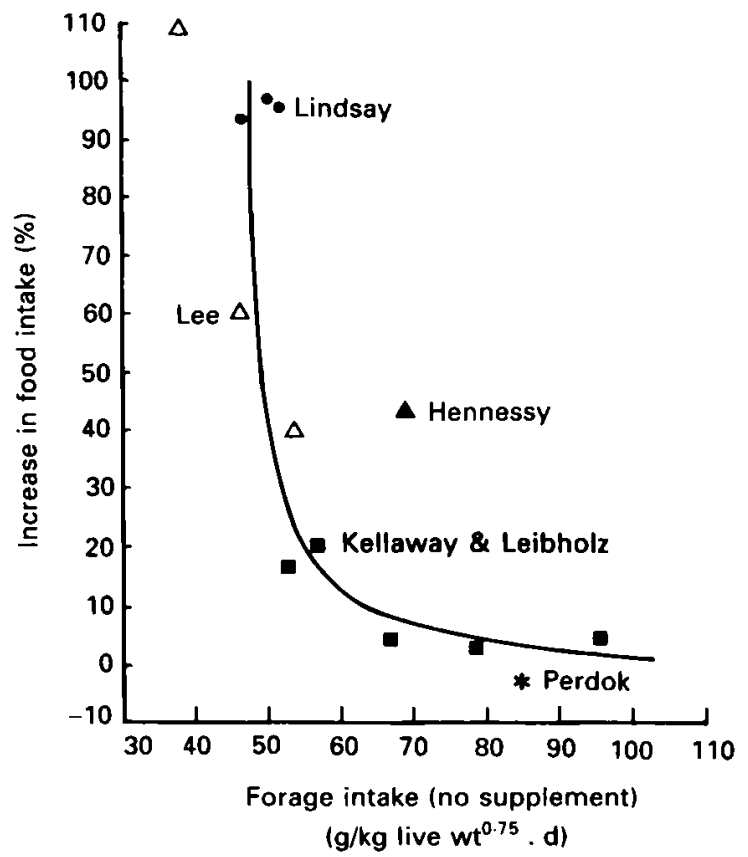

Fig. 5. Intake of low-quality forage by cattle (studies are only considered from Australia) in relation to intake of the forage following supplementation with a bypass protein meal or bypass protein meal plus urea in different climatic zones (Leng, 1989). The research of Lindsay \& Loxton (1981), Lindsay $e t$ al. (1982) (O), Lee et al. (1987) ( $\Delta$ ) and Hennessy (1984) (A) was done at sites in the tropics or subtropics, whereas the research of Kellaway \& Leibholz (1981) (D) and Perdok (1987) ( $\downarrow$ ) was done under more temperate climate conditions.

\section{CLIMATE, SUPPLEMENTATION AND INTAKE OF LOW-QUALITY FORAGES}

There has been vigorous debate on whether supplementation of sheep and cattle on lowquality forage-based diets with urea and/or bypass protein increases intake of the basal feed resource (see Leng, 1990). The differences in results may be attributed to an interaction between climate and the balance of nutrients available from a diet. When Australian research results on the effects of supplementation of cattle on low-quality forages are grouped according to climatic zones a pattern emerges (Fig. 5). It appears to be in the tropics and subtropics, where poor-quality forage intake by cattle is low without supplementation, that significant responses in feed intake occur when a non-protein- $N$ deficiency is corrected and extra protein that escapes rumen fermentation is provided in the diet. Supplementation with urea and protein meals increases voluntary intake of poorquality forages by cattle under tropical conditions to approximately the same level of intake as unsupplemented cattle under temperate conditions (Leng, 1990). The conclusion that can be drawn from this is that supplements which improve the $P$ : $E$ ratio in nutrients absorbed by cattle fed on low-quality forage reduce metabolic heat production. Where metabolic heat production in unsupplemented cattle fed on low-quality forages would increase body temperature then the animal reduces its feed intake. This reduction in voluntary feed intake is ameliorated by the supplement which allows the acetogenic substrate which would otherwise have to be oxidized to be partitioned into synthetic reactions with a resultant decrease in heat production (Leng, 1989 b). 


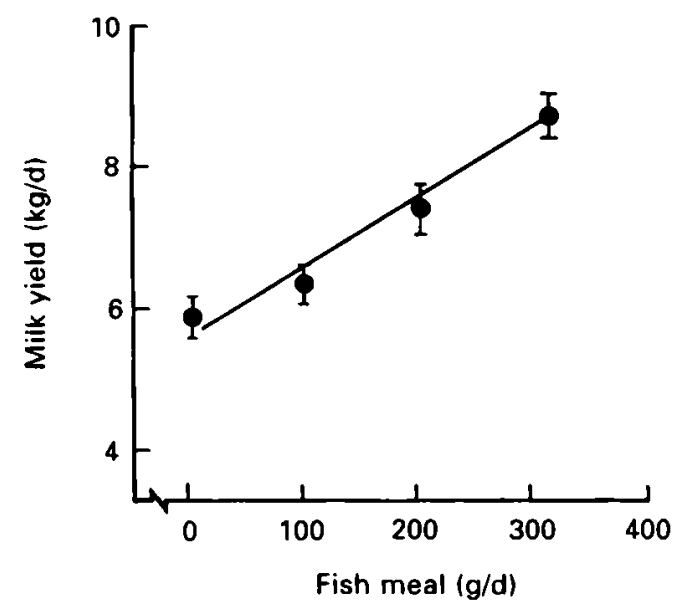

Fig. 6. Response in milk yield to supplements of fish meal of native and crossbred cattle fed on ammoniated rice straw in Bangladesh (see Saadullah, 1984).

The interaction of nutrition and climate may explain why there is a disbelief by some researchers from developed countries (largely in the temperate areas) of research carried out in developing countries in the tropics which has demonstrated that supplementation with a protein that escapes rumen fermentation stimulates both the level and efficiency of production of milk (Fig. 6) or live-weight gain (Table 5) in ruminants fed on crop residues.

The previous discussion indicates that ruminants in hot countries have an advantage of not having to oxidize much acetogenic substrate (or body fat) to keep warm. This acetogenic substrate may, therefore, be captured in products by balancing the diet, with supplements. In cold/cool countries supplementation with protein is less necessary as the utilization of surplus acetate for heat decreases the need to balance nutrients (see Table 4). As long as feed intake is high (i.e. the diet is highly digestible and perhaps cold stress stimulates intake) production remains relatively high as the nutrients for heat production are extracted and the balance used in synthetic reactions. Nevertheless, increases in the efficiency of utilization are obtained when low-protein diets are supplemented with a bypass protein even in temperate countries (see Ørskov, 1970; Leng et al. 1977; Silva et al. 1989).

It can be concluded that ruminants in the tropics that are adequately supplemented with small quantities of essential nutrients may produce at the same rate on a lower-digestibility feed as an animal on a higher-digestibility feed in a cold environment. The reasons for this become apparent if some calculations of the available nutrients are made from stoichiometric considerations (see Tables 4 and 5).

To emphasize the differences in potential thermal stress of animals under different conditions the average temperature humidity index (THI; which is an index of potential heat stress conditions for ruminants (see Johnson, 1987)) on a monthly basis for Cambridge (England), Dhaka (Bangladesh), Bangkok (Thailand) and Armidale (Australia) are shown in Fig. 7. The critical THI (72) for high-milk-producing cows as determined by Johnson (1987) is included in Fig. 7, but in addition to mean daily temperatures/humidities, the critical THI will depend on the insulation provided by the animal's coat and its behaviour in seeking shelter, as well as the incidence of wind and rain in addition to level and quality of feed intake. 
Table 5. A theoretical assessment of the effects of cold stress on the balance of nutrients available to a sheep given $1200 \mathrm{~g}$ dried grass cubes with 60,50 or $40 \%$ digestibility/d

\begin{tabular}{|c|c|c|c|c|c|c|}
\hline \multirow{2}{*}{ 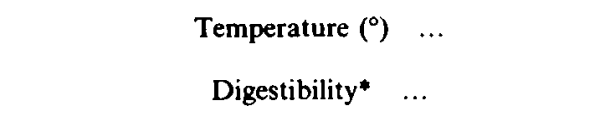 } & \multicolumn{3}{|c|}{33} & \multirow{2}{*}{$\begin{array}{c}31 \cdot 5 \\
60\end{array}$} & \multirow{2}{*}{$\begin{array}{l}29 \\
60\end{array}$} & \multirow{2}{*}{$\begin{array}{r}27.5 \\
60\end{array}$} \\
\hline & 60 & 50 & 40 & & & \\
\hline Metabolizable energy available $\dagger(\mathrm{MJ} / \mathrm{d})$ & 9.8 & 8.1 & 6.5 & 9.8 & 9.8 & 9.8 \\
\hline VFA oxidized to counteract cold stress $\ddagger(\mathrm{MJ} / \mathrm{d})$ & 0 & 0 & 0 & $1 \cdot 1$ & $2 \cdot 2$ & 3.3 \\
\hline VFA produced§ $(\mathrm{MJ} / \mathrm{d})$ & $5 \cdot 4$ & 4.5 & 3.6 & $5 \cdot 4$ & $5 \cdot 4$ & 5.4 \\
\hline VFA available $\|(\mathrm{MJ} / \mathrm{d})$ & $5 \cdot 4$ & $4 \cdot 5$ & $3 \cdot 6$ & $4 \cdot 3$ & $3 \cdot 2$ & $2 \cdot 1$ \\
\hline Microbial protein $\|(\mathrm{g} / \mathrm{d})$ & 148 & 123 & 98 & 148 & 148 & 148 \\
\hline Available $\mathrm{P}: \mathrm{E}$ ratio** $(\mathrm{g} / \mathrm{MJ})$ & $27: 1$ & $27: 1$ & 27:1 & $34: 1$ & $46: 1$ & $70: 1$ \\
\hline Available G:E ratio $\dagger$ (MJ/MJ) & $0 \cdot 25: 1$ & $0 \cdot 25: 1$ & $0 \cdot 25: 1$ & $0.33: 1$ & $0.50: 1$ & 1.04:1 \\
\hline
\end{tabular}

VFA, volatile fatty acids. Available $\mathbf{P}: \mathbf{E}$ ratio: calculated microbial protein available (g) for digestion relative to VFA produced (MJ). Available G:E ratio: propionate (MJ): acetate plus butyrate (MJ) available.

- Digestibility of this ration was $60 \%$ (Graham et al. 1959). The theoretical availability of nutrients from a similar feed at 50 and $40 \%$ digestibility are also shown.

$\dagger$ Metabolizable energy availability at minimum heat production by the animal (Graham et al. 1959).

$\ddagger$ Calculated assuming $0.44 \mathrm{MJ} / \mathrm{d}$ are required to counteract $1^{\circ}$ drop in temperature below the minimum critical temperature, i.e. $33^{\circ}$ for sheep on this ration (Graham et al. 1959).

$\S$ Calculated from stoichiometric principles (Leng, 1982).

II Assumes that only VFA are oxidized to counteract cold stress.

- Calculated from stoichiometric principles (Leng, 1982).

** Calculated assuming that the cold stress is met by oxidation of acetic and butyric acid and that amino acid catabolism is unaffected by cold stress.

it Calculated assuming that the heat for counteracting cold stress is generated by the oxidation of acetate and butyrate and that propionate is not oxidized for this purpose.

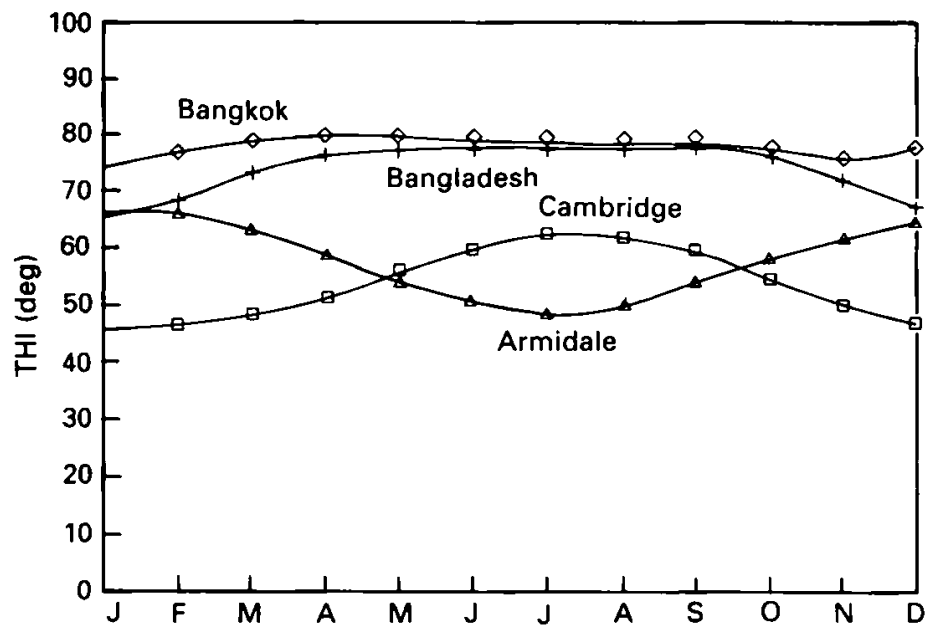

Fig. 7. Temperature humidity index (THI) of climates in temperate countries as exemplified by Cambridge (UK) and Armidale (Australia) as compared with tropical countries as exemplified by Bangkok (Thailand) and Mymensingh (Bangladesh). The THI is calculated on the mean of the maximum-minimum temperatures and humidities: $\mathrm{THI}\left({ }^{\circ}\right)=$ temperature (dry bulb) +0.36 temperature (dew-point) $+41 \cdot 2^{\circ}$. 


\section{EFFICIENCY OF FEED UTILIZATION AND ACETATE AVAILABILITY TO RUMINANTS}

The original calorimetric studies of Graham and his colleagues (see Blaxter, 1962) indicated that infused acetate or butyrate was utilized by sheep with low efficiencies, i.e. there was a high heat increment when acetate was given compared with propionate. Considerable effort has since been expended on testing the hypothesis (or disproving it) that acetogenic substrate is used wastefully. Blaxter and his colleagues (Graham et al. 1959) used diets based on dried grass which was chopped and cubed. It had an M/D of about $8.5 \mathrm{MJ} / \mathrm{kg}$. As most of the protein in the diet could have been highly soluble, the $\mathrm{P}: \mathrm{E}$ ratio in absorbed nutrients may have been relatively low.

The controversy concerning the efficiency with which acetogenic substrate is utilized may be rationalized at least to some extent by considering the balances of nutrients available to the ruminants in the various experiments and the ability or otherwise of the animals to synthesize fat, dissipate heat or to oxidize substrate to keep warm.

It is impossible to obtain the relevant information from the reports of previous research and, therefore, an explanation is advanced here as a hypothesis that might be tested in the future.

The heat increment of added acetogenic substrate will depend on the pattern of fermentation in the rumen (i.e. the ratio of glucogenic:acetogenic substrate produced) and the balance of protein available for digestion and absorption from the intestines and VFA produced. For example, the presence of small amounts of fish meal, a protein meal that escapes the rumen in considerable amounts, in a concentrate diet provides a possible explanation for the differences between the results of Ørskov \& Allen (1966) and those summarized by Blaxter (1962) where sheep were fed on dried grass which may have contained a highly soluble source of protein.

Sheep or cattle that need to oxidize acetate (the major thermogenic substrate) to keep warm may utilize an acetogenic load highly efficiently compared with ruminants under climatic conditions with a high THI. Ruminants confined to calorimeters are usually maintained at what is supposed to be thermoneutrality. However, animals in feeding trials exposed to heat and/or cold stress will respond metabolically according to the insulative properties of the coat or fleece.

The third difference to explain why at times acetogenic substrate is efficiently used, but which probably seldom arises in research studies, is the fact that acetogenic substrate is the major source of ATP for muscle metabolism (Pethick, 1984).

The many studies that have shown, at the same forage intake by ruminants with an already efficient digestion, that a supplement of protein that reaches the small intestine increases the efficiency of feed or ME utilization for growth indicates that wasteful oxidation of nutrients can occur (see Fig. 8 and Table 6). It seems reasonable that, because Blaxter (1962) showed that acetogenic substrates are largely 'burned off', that the inefficiency of ruminants on forage-based diets is a result of acetate being oxidized wastefully. Studies, however, are necessary now to examine in great detail the interactions of climate and nutrition on the partitioning of acetate into oxidative or synthetic pathways.

\section{METABOLIZABLE ENERGY AS AN INDICATOR OF FEED QUALITY OF LOW-DIGESTIBILITY FORAGES}

In this section, the efficiency of feed utilization refers to the ME (digestible energy $\times 0.82$ ) consumed relative to the live-weight gain. There are a number of findings which show that 
Table 6. Live-weight gain $(\triangle L W t)$ and feed conversion ratio $(F C R)$ of lambs fed on highand low-quality diets (Leng, 1989 b)

\begin{tabular}{|c|c|c|c|c|c|}
\hline \multirow[b]{2}{*}{ Basal } & \multirow[b]{2}{*}{$\begin{array}{l}\text { Quality } \\
\text { status }\end{array}$} & \multirow{2}{*}{$\begin{array}{c}\text { Approximate } \\
\text { digestibility } \\
(\%)\end{array}$} & \multirow{2}{*}{$\begin{array}{l}\text { Growth } \\
\text { rate } \\
(\mathrm{g} / \mathrm{d})\end{array}$} & \multicolumn{2}{|c|}{ FCR } \\
\hline & & & & $\mathrm{g} / \mathrm{g} \Delta \mathrm{LWt}$ & $\begin{array}{l}\text { g DOM/ } \\
\text { g } \Delta L W t\end{array}$ \\
\hline Cottonseed hulls (CSH)* & Low & 40 & 75 & $16: 1$ & $6: 1$ \\
\hline $\mathrm{CSH}+$ formal-casein ${ }^{*}$ & Low & 40 & 138 & $8: 1$ & $3: 1$ \\
\hline Rice straw (RS) + UMB $†$ & Low & 42 & 10 & $50: 1$ & $21: 1$ \\
\hline $\mathrm{RS}+120 \mathrm{~g} \mathrm{CSM}+\mathrm{UMB}+$ & Low & 42 & 90 & $8: 1$ & $3: 1$ \\
\hline Clover-ryegrass $\ddagger$ & High & 80 & 143 & $8: 1$ & $6: 1$ \\
\hline Grain-hay $\ddagger$ & High & 80 & 130 & $6: 1$ & $5: 1$ \\
\hline Grain/hay + fish mealf & High & 80 & 253 & $5: 1$ & $4: 1$ \\
\hline Barley + urea $\S$ & High & 80 & 224 & $4: 1$ & $3: 1$ \\
\hline Barley + fish meal§ & High & 80 & 332 & $3: 1$ & $2: 1$ \\
\hline
\end{tabular}

DOM, digestible organic matter; UMB, urea-molasses block.

- Davis \& Leng (1988).

$\dagger$ Sudana \& Leng (1986).

$\ddagger$ Geenty et al. (1987).

$\S$ Ørskov et al. (1970)

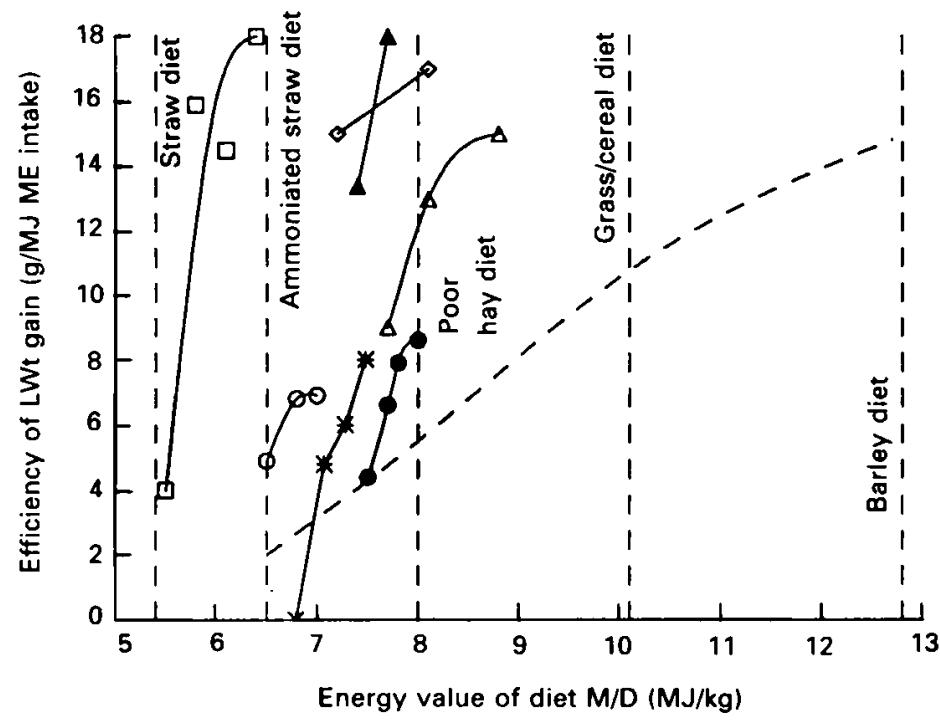

Fig. 8. A schematic relationship between diet quality (metabolizable energy (ME)/kg dry matter) and feed conversion efficiency (g live-weight (LWt) gain/MJ ME) (from Webster, 1989). The relationships found in practice with cattle fed on straw or ammoniated straw with incremental amounts of supplements in Australia $(\diamond, O, O)$ (Perdok et al. 1988), Thailand $(\triangle)$ (Wanapat et al. 1986) and Bangladesh $(\square)$ (Saadullah, 1984). The results of Godoy \& Chicco (1990) ( $\star$ ) were obtained with cattle on tropical pasture hay harvested in the dry season and supplemented with cottonseed meal in Venezuela. Hennessy et al. (1989) (A) used cattle fed on a poor-quality tropical hay supplemented with copra meal. The values illustrate the marked differences in efficiency that result when supplements high in protein are given to cattle on diets of low ME content. 
sheep and cattle on so-called 'poor'- or 'high'-quality feeds often have comparable efficiencies of feed utilization (Table 6). This is difficult to reconcile with classical feeding standards based on ME values.

That the M/D of a feed may not, in practice, predict production levels with any degree of accuracy is illustrated by comparing the levels of production obtained in cattle on lowquality forage (supplemented to give efficient digestion and metabolism in the animal) with the classical findings relating $M / D$ to efficiency of gain (g gain/MJ ME). Schematic illustration of the classical effects of increasing feed quality $(\mathrm{M} / \mathrm{D} ; \mathrm{MJ} / \mathrm{kg})$ on the efficiency of conversion of $\mathrm{ME}$ into live-weight gain ( $\mathrm{g}$ gain/MJ) in calves from Friesian cows is shown in Fig. 8. Some relationships found in practice where straw-based diets have been given to cattle and supplemented with urea-minerals and varying levels of supplements designed to provide protein to the intestine are also shown in Fig. 8.

Webster (1989) has pointed out that given a poor-quality diet of hay (M/D 8) the Friesian $\times$ Hereford cross steer achieves only $4 \mathrm{~g}$ gain/MJ ME rising to $14.5 \mathrm{~g}$ gain/MJ ME on a barley-beef ration (M/D 12.5). This is difficult to reconcile with the efficiency of cattle growth in the tropics on so-called low-quality straw (treated or untreated with ammonia to increase digestibility) and supplemented with increasing levels of a protein meal that provides substantial quantities of amino acids for absorption (cottonseed meal). In the studies shown in Fig. 8, conversion of ME to live-weight gain varied between 15 and $18 \mathrm{~g}$ gain/MJ in both Friesian and Zebu calves grown over considerable live-weight increments (Saadullah, 1984; Wanapat et al. 1986; Perdok et al. 1988). These efficiencies are achieved despite growth rates being considerably less than that of cattle in a barley-beef feeding system (i.e. $0.5-0.95$ v. $1.2-1.5 \mathrm{~kg} / \mathrm{d}$ respectively; Fig. 8 ).

It is tempting to suggest that the differences of the results obtained in practice compared with those predicted (Webster, 1989) are a result of a cold stress in the animals in a temperate country relative to those in Australia, Thailand or Bangladesh. However, it is more likely that the high feed-conversion efficiencies on the straw diets are a combination of there being no requirement for heat production to counteract cold stress and an efficient utilization of nutrients due to the more appropriate balance (adjusted by the supplements) of nutrients in the animals (Saadullah, 1984; Wanapat et al. 1986; Perdok et al. 1988).

Silva et al. (1989) recently reported growth trials with cattle which also showed some remarkably high efficiencies of utilization of $\mathrm{ME}$ for growth on straw-based diets with efficiencies greatly exceeding $14 \mathrm{~g}$ gain/MJ ME. This research showed that a protein-meal supplement improved both growth and efficiency whereas a supplement of sugar-beet pulp (an energy supplement) increased the growth rate but lowered growth efficiency (Table 7).

It is possible that the heat generated in meeting maintenance requirements has been overestimated in cattle and sheep in advanced laboratories. For this to have occurred the maintenance heat production as measured must have had a large component of heat generated wastefully, as for example would occur where the nutrients available to the animal were only from fermentative digestion. The possible overestimate of nutrient utilization for maintenance of homeostasis may be attributable to an imbalanced array of nutrients in the animal. In the temperate countries, or with animals under laboratory conditions in their zone of thermoneutrality, the heat would be dissipated without difficulty. However, in a hot country with animals at THI close to the upper limit of the zone of thermoneutrality, this extra heat could cause a heat stress, resulting in a decrease in feed intake.

It may be concluded that the ME system is inadequate for prediction of levels of ruminant production, particularly for 'low-quality' feeds. Protein supplements that are digested in the intestines improve efficiency of feed utilization, which is the predominant response in climates that allow easy dissipation of metabolically generated heat. On the 
Table 7. The relationship between metabolizable energy $(M E)$ :dry matter $(D M)(M / D$; $M J / \mathrm{kg}$ ) and efficiency ( $\mathrm{g}$ gain $/ M J M E$ ) in cattle fed on untreated straw (US) or ammoniated straw $(A S)$ with supplements of fish meal (FM; $50 \mathrm{~g} / \mathrm{kg}$ straw) or sugar-beet pulp (SBP; $150 \mathrm{~g} / \mathrm{kg}$ straw)

\begin{tabular}{|c|c|c|c|c|c|c|}
\hline \multirow[b]{2}{*}{ Treatment } & \multicolumn{3}{|c|}{ Expt 3} & \multicolumn{3}{|c|}{ Expt 2} \\
\hline & $\begin{array}{l}\text { LWt gain } \\
(\mathrm{g} / \mathrm{d})\end{array}$ & $\begin{array}{c}\text { M/D } \\
(\mathrm{MJ} / \mathbf{k g})\end{array}$ & $\begin{array}{c}\text { Efficiency } \\
\text { (g LWt } \\
\text { gain/MJ) }\end{array}$ & $\begin{array}{l}\text { LWt gain } \\
(\mathrm{g} / \mathrm{d})\end{array}$ & $\begin{array}{c}M / D \\
(\mathrm{MJ} / \mathrm{kg})\end{array}$ & $\begin{array}{c}\text { Efficiency } \\
\text { (g LWt } \\
\text { gain/MJ) }\end{array}$ \\
\hline US & -24 & 6.0 & - & -97 & 6.0 & - \\
\hline $\mathrm{US}+\mathrm{FM}$ & 176 & $6 \cdot 4$ & $5 \cdot 3$ & 373 & 6.5 & $15 \cdot 0$ \\
\hline $\mathrm{US}+\mathrm{SBP}$ & 183 & $7 \cdot 1$ & $4 \cdot 5$ & 363 & $8 \cdot 1$ & 8.8 \\
\hline $\mathrm{US}+\mathrm{SBP}+\mathrm{FM}$ & 337 & $7 \cdot 7$ & $6 \cdot 6$ & 627 & $7 \cdot 3$ & 18.0 \\
\hline AS & 198 & $7 \cdot 0$ & $4 \cdot 6$ & 713 & 7.0 & $19 \cdot 2$ \\
\hline $\mathrm{AS}+\mathbf{F M}$ & 423 & $7 \cdot 4$ & 8.6 & 820 & $7 \cdot 3$ & 22.0 \\
\hline $\mathrm{AS}+\mathrm{SBP}$ & 262 & 8.0 & $4 \cdot 7$ & 763 & 7.9 & $18 \cdot 0$ \\
\hline $\mathrm{AS}+\mathrm{SBP}+\mathrm{FM}$ & 814 & $8 \cdot 3$ & $12 \cdot 6$ & 1240 & $8 \cdot 2$ & $22 \cdot 1$ \\
\hline
\end{tabular}

LWt, live weight.

These values were calculated from the results of feeding trials reported by Silva et al. (1989). It is assumed that the supplements contained $14 \mathrm{MJ} / \mathrm{kg} \mathrm{DM}$ and that untreated straw had $6 \mathrm{MJ} / \mathrm{kg} \mathrm{DM}$ and treated straw $7 \mathrm{MJ} / \mathrm{kg} \mathrm{DM}$.

other hand, protein supplements increase a depressed feed intake and improve efficiency of feed utilization in ruminants in tropical climates.

Ruminants evolved under a system whereby they were able to migrate when pasture quality or quantity became limiting. Under these conditions, an excess of acetate above that required for homeostasis and production levels (largely set by digestible feed intake) was not a waste as the excess acetate could be oxidized and work undertaken. In an animal that was without food for some time, the nutrients mobilized were needed to meet maintenance and to perform the work necessarily expended in moving to fresh pasture. Where fasting heat production and maintenance energy requirements have been estimated in warm laboratories under sedentary conditions, it is feasible that heat production would be higher than that required if the mobilized nutrients were similar to those mobilized under fasting and migration of ruminants. It would have been advantageous for survival of the species to mobilize more acetogenic substrate than required for maintenance of homeostasis. These considerations could explain the high efficiencies of feed utilization seen when protein meals are supplemented to ruminants on poor-quality pastures.

From time to time similar attempts to rationalize research results have appeared in the literature. Kronfeld (1976) discussed the relationship between acetogenic, glucogenic and aminogenic substrates for milk production in cattle. Kleiber in the 1960s suggested that 'Metabolisable energy is not a homogeneous entity, instead it represents an assembly of nutrients or metabolites each of which is used with a specific efficiency for a particular purpose' (Kronfeld, 1976).

Recently Baldwin et al. (1985) have pointed out that maintenance energy metabolism can vary over a two- to three-fold range in animals of the same weight. These authors drew attention to the arbitrary value of the concept that basal or resting metabolism (in units of heat production $(x)$ ) in young adult animals is described by the allometric equation:

where $w$ is live weight.

$$
x=70+\mathrm{w}^{0 \cdot 75}
$$


Thonney et al. (1976) using regression analysis of maintenance energy requirements and live weight for various animal species showed that the exponent of weight that best fitted the data varied between 0.37 and 0.74 . Cañas et al. (1982) held the exponent of weight at 0.75 and showed that the coefficient varied from 167 to $585 \mathrm{~kJ}(40-140 \mathrm{kcal})$ both between and within a species.

Baldwin et al. (1985) have also drawn attention to the fact that allometric equations may be expected to vary with age, previous plane of nutrition and physiological state of the animal. It is now clear that thermal environment, previous health history and most importantly the $\mathrm{P}: \mathrm{E}$ ratio in the nutrients absorbed can be added to this list.

\section{CONCLUSIONS}

The major conclusion that arises from the present review is that information on $\mathrm{ME}$ and CP content of a feed has little bearing on how animals utilize their feed without measurements made within the rumen and within the animal. It is suggested that the traditional approach should be abandoned for forage-based diets under tropical conditions.

It is difficult to define exactly the approach that is needed in practice but, in principle, the knowledge required to predict production levels will include digestibility, protein availability in the intestines, the efficiency of nutrient utilization, the physiological state of the animal, its previous dietary and health history and the THI. The animal's genetic potential for growth may have little bearing on the production levels achieved on foragebased diets where ruminants are supplemented to ensure efficient utilization of feed. However, as has been discussed elsewhere (Leng, 1990), there is a remarkable interaction between the genetic potential for milk production by cattle and the balance of available nutrients for milk production, particularly by cattle in the tropics.

Greater understanding of nutrient requirements by animals as against requirements for ME when widely interpreted and extended into feeding strategies could have enormous effects on the levels of productivity of ruminants that presently subsist on poor-quality forages in the tropics.

There will always be interactions that are not foreseen by the nutritionist but the approach to developing diets or supplements based on the concepts of stimulating an efficient digestive system and efficient metabolism in the animal will, it is suggested, always be more appropriate than predictions based on the chemical analysis of the feed or its $\mathrm{ME}$ content. The findings presented on the efficiency with which straw can be potentially used by cattle also indicate basic deficiencies in the standards presently used. With low-quality forage diets the traditional model predicts efficiencies of growth of cattle that may be less than half those of cattle on diets supplemented to achieve the two criteria listed previously. In the view of the author there seems to be little choice but to develop a scheme to take account of different environments and responses to inputs of proteins that are digested and absorbed from the intestines.

The most important knowledge will be the protein content of a diet and the degee to which the protein escapes the fermentative digestive system of the animal and the digestibility of the feed available.

The discussion and hypotheses developed in the review need validation and research. Much of the stimulus to consider environmental heat stress was drawn from practical observations where the concepts of balanced nutrition have been applied on a large scale with highly beneficial responses (see report of the National Dairy Development Board of India (NDDB)). The practical outcome of the questioning of traditional views has, I believe, been more enlightened feeding systems for practical use in countries that depend 
for their feed base for ruminants on crop residues and agro-industrial by-products (Preston \& Leng, 1987).

The application of the concepts developed may have enormous effects on the well-being of small farmers in many countries such as India, who have no choice of basal diets and must depend largely on straw for their livestock.

The author wishes to thank Dr J. V. Nolan for discussions and Dr J. Argyle particularly for discussion on bacterial metabolism.

\section{REFERENCES}

Allison, M. J., Bryant, M. P. \& Doetsch, R. N. (1962). Studies on the metabolic function of branched-chain volatile fatty acids, growth factors for Ruminococci. I. Incorporation of isovalerate into leucine. Journal of Bacteriology 83, 523-532.

Annison, E. F. \& Lewis, D. (1959). Metabolism in the Rumen. London: Methuen.

Argyle, J. L. \& Baldwin, R. L. (1989). Effects of amino acids and peptides on rumen microbial growth yields. Journal of Dairy Science 72, 20172027.

Baldwin, B. R., Forsberg, N. E. \& Hu, C.-Y. (1985). Potential for altering energy partition in the lactating cow. Journal of Dairy Science 68, 3396-3402.

Ben-Ghedalia, D. \& Yosef, E. (1989). $\mathrm{SO}_{2}$-treated straw as a silage additive: fermentation data on lucerne with particular reference to protein degradation. Animal Feed Science and Technology 22, 247-254.

Bird, S. H. (1989). Production from ciliate-free ruminants. In The Roles of Protozoa and Fungi in Ruminant Digestion, pp. 233-246 [J. V. Nolan, R. A. Leng and D. I. Demeyer, editors]. Armidale, Australia : Penambul Books.

Bird, S. H., Hill, M. K. \& Leng, R. A. (1979). The effects of defaunation of the rumen on the growth of lambs on low-protein high-energy diets. British Journal of Nutrition 42, 8187.

Bird, S. H. \& Leng, R. A. (1978). The effects of defaunation of the rumen on the growth of cattle on low-protein high-energy diets. British Journal of Nutrition 40, 163-167.

Bird, S. H. \& Leng, R. A. (1985). Productivity responses to eliminating protozoa from the rumen of sheep. In Biotechnology and Recombinant DNA Technology in the Animal Production Industries - Reviews in Rural Science 6, pp. 109-117 [R. A. Leng, J. S. F. Barker, D. B. Adams and K. J. Hutchinson, editors]. Armidale, Australia: University of New England.

Bird, S. H., Nolan, J. V. \& Leng, R. A. (1990). Nutritional significance of rumen protozoa. Paper presented at VIIth International Symposium on Ruminant Physiology (1989), Satellite Symposium on Regulation of Microbial Metabolism in the Rumen Ecosystem. Hakone, Japan. (In the Press.)

Blaxter, K. L. (1962). The Energy Metabolism of Ruminants. London: Hutchinson.

Boniface, A. M., Murray, R. M. \& Hogan, J. P. (1986). Optimum level of ammonia in the rumen liquor of cattle fed tropical pasture hay. Proceedings of the Australian Society of Animal Production 16, 15I-154.

Bray, A. C. \& Till, A. R. (1975). Metabolism of sulphur in the gastro-intestinal tract. In Digestion And Metabolism In The Ruminant, pp. 243-260 [I. W. McDonald and A. C. I. Warner, editors]. Armidale, Australia : University of New England Publishing Unit.

Bryant, M. P. \& Robinson, I. M. (1961a). Studies on the nitrogen requirements of some ruminal cellulolytic bacteria. Applied Microbiology 9,96-103.

Bryant, M. P. \& Robinson. I. M. (1961 b). Some nutritional requirements of the genus Ruminococcus. Applied Microbiology 9, 91-95.

Bryant, M. P. \& Robinson, I. M. (1962). Some nutritional characteristics of predominant culturable ruminal bacteria. Journal of Bacteriology 84, 605614.

Bryant, M. P. \& Robinson, I. M. (1963). Apparent incorporation of ammonia and amino acid carbon during growth of selected species of ruminal bacteria. Journal of Dairy Science 46, 150-154.

Cañas, R., Romero, J. J. \& Baldwin, R. L. (1982). Maintenance energy requirements during lactation in rats. Journal of Nutrition 112, 1876-1880.

Chalupa, W. (1980). Chemical control of rumen microbial metabolism. In Digestive Physiology and Metabolism in the Ruminant, pp. 325-347 [Y. Ruckebusch and P. Thivend, editors]. Lancaster : MTP Press.

Cheng, K. J., Forsberg, C. W., Minato, H. \& Costerton, J. W. (1990). Microbial ecology and physiology of feed degradation within the rumen. Paper presented at VIIth International Symposium on Ruminant Physiology. Sendai, Japan. (In the Press.)

Cotta, M. A. \& Russell, J. B. (1982). Effect of peptides and amino acids on efficiency of rumen bacterial protein synthesis in continuous culture. Journal of Dairy Science 65, 226-234.

Davis, J. J. \& Leng, R. A. (1988). Cottonseed hulls as a feed for sheep. In Recent Advances in Animal Nutrition in Australia 1989, p. 33 A Abstr. [D. J. Farrell, editor]. Armidale, Australia: University of New England, Department of Biochemistry, Microbiology and Nutrition. 
Devendra, C. (1990). Comparative aspects of digestive physiology and nutrition in goats and sheep. Paper presented at Satellite Symposium on Ruminant Physiology and Nutrition in Asia. Sendai, Japan (1989). (In the Press.)

Durand, M., Beaumatin, Ph., Dumay, C., Maschy, R. \& Komisarczuk, S. (1986). Influence de l'addition de phosphore sur la digestion d'une paille traitée à l'ammoniac par les microorganisms du rumen en fermenteur semi-continu (Rusitec). (Influence of phosphorus addition on the digestion of ammonia-treated straw by rumen micro-organisms in a semi-continuous fermenter (Rusitec).) Reproduction Nutrition Développement 26, $297-298$.

Durand, M. \& Komisarczuk, S. (1988). Influence of major minerals on rumen microbiota. Journal of Nutrition 118, 249-260.

Elliott, R. C. \& O'Donovan, M. W. (1971). In Report - Henderson Research Station, Harare, Zimbabwe.

Forster, R. J. \& Leng, R. A. (1989). The effect of varying protozoal population and diet supplementation on wool growth. In The Roles of Protozoa and Fungi in Ruminant Digestion, pp. 331-332 [J. V. Nolan, R. A. Leng and D. I. Demeyer, editors]. Armidale, Australia: Penambul Books.

Geenty, K. G., Smith, M. C. \& Bartley, K. (1987). Effects of varying levels of dietary protein on lamb growth rate and carcass composition. In 4th Australasian Asian Association of Animal Production Animal Science Congress, p. 360 [T. F. Reardon, J. L. Adam, A. G. Campbell and R. M. W. Sumner, editors]. Hamilton, New Zealand: New Zealand and Australian Society of Animal Production.

Godoy, S. \& Chicco, C. (1990). Annual Report-FONIAP. Maracay, Venezuela: Fondo Nacional de Investigaciones Agropecuaries.

Gordon, G. L. R. \& Phillips, M. W. (1989). Comparative fermentation properties of anaerobic fungi from the rumen. In The Roles of Protozoa and Fungi in Ruminant Digestion, pp. 127-138 [J. V. Nolan, R. A. Leng and D. I. Demeyer, editor]. Armidale, Australia: Penambul Books.

Graham, N. McC., Wainman, F. W., Blaxter, K. L. \& Armstrong, D. G. (1959). Environmental temperature, energy metabolism and heat regulation in sheep. I. Energy metabolism in closely clipped sheep. Journal of Agricultural Science 52, 13-24.

Habib, G., Nolan, J. V. \& Leng, R. A. (1989). Fermentative digestion and metabolism in faunated or fauna-free lambs fed roughage-based diets. In The Roles of Protozoa and Fungi in Ruminant Digestion, pp. $323-326$ [J. V. Nolan, R. A. Leng and D. I. Demeyer, editors]. Armidale, Australia: Penambul Books.

Hegarty, R. S., Nolan, J. V. \& Leng, R. A. (1989). Evidence for protozoa influencing rumen sulphur availability. In The Roles of Protozoa and Fungi in Ruminant Digestion, pp. 305-306 [J. V. Nolan, R. A. Leng and D. I. Demeyer, editors]. Armidale, Australia : Penambul Books.

Hemsley, J. A. \& Moir, R. J. (1963). The influence of higher volatile fatty acids on the intake of ureasupplemented low quality cereal hay by sheep. Australian Journal of Agricultural Research 14, 509-517.

Hennessy, D. W. (1984). The role of protein in improving production of cattle grazing native pastures in subtropical New South Wales. PhD Thesis, University of New England, Armidale, Australia.

Hobson, P. N., Chesson, A. \& Forsberg, C. W. (1988). Polysaccharide degradation by rumen microorganisms. In The Rumen Microbial Ecosystem, pp. 251-284 [P. N. Hobson, editor]. London: Elsevier Applied Science.

Hobson, P. N., McDougall, E. I. \& Summers, R. (1968). The nitrogen sources of Bacteroides amylophilus. Journal of General Microbiology 50, i Abstr.

Hume, I. D. (1970). Synthesis of microbial protein in the rumen. III. The effect of dietary protein. Australian Journal of Agricultural Research 21, $305-314$.

Hungate, R. E. \& Dyer, I. A. (1956). Effect of valeric and isovaleric acids on straw utilization by steers. Journal of Animal Science 15, 485-488.

Hunter, R. A. (1988). Some aspects of the role of concentrates in increasing feed intake and productivity of cattle fed fibrous diets. In Ruminant Feeding Systems Utilizing Fibrous Agricultural Residues - 1987, pp. 37-48 [R. M. Dixon, editor]. Canberra, Australia: Australian International Development Programme.

Ivan, M. (1989). The involvement of rumen protozoa in copper metabolism and animal health. In The Roles of Protozoa and Fungi in Ruminant Digestion, pp. 199-210 [J. V. Nolan, R. A. Leng and D. I. Demeyer, editors]. Armidale, Australia: Penambul Books.

Jackson, M. G. (1981). A new livestock development strategy for India. World Animal Review No. 37,28

Johnson, H. D. (1987). Bioclimates and livestock. In Bioclimatology and the Adaptation of Livestock, pp. $3 \cdot 16$ [H. D. Johnson, editor]. Amsterdam: Elsevier Science Publications.

Jouany, J. P. \& Ushida, K. (1990). Protozoa and fibre digestion in the rumen. Paper presented at the VIIth ISRP Satellite Symposium on Regulation of Microbial Metabolism in the Rumen Ecosystem. Hakone, Japan (1989). (In the Press.)

Juul-Nielson, J. (1981). Nutritional principles and productive capacity of the Danish straw-mix system for ruminants. In Maximum Livestock Production from Minimum Land, pp. 287-299 [M. G. Jackson, F. Dolberg, M. Haque and M. Saadullah, editors]. Mymensingh, Bangladesh: Bangladesh Agricultural University.

Kandylis, K. (1984). Toxicology of sulfur in ruminants: a review. Journal of Dairy Science 67, $2179-2187$.

Kay, R. N. B. \& Phillipson, A. T. (1964). The influence of urea and other dietary supplements on the nitrogen content of the digesta passing to the duodenum of hay-fed sheep. Proceedings of the Nutrition Society 23, xlvi Abstr.

Kellaway, R. C. \& Leibholz, J. (1981). Effects of nitrogen supplements on intake and utilization of low quality 
forages. In Recent Advances in Animal Nutrition in Australia-1981, pp. 66-73 [D. J. Farrell, editor]. Armidale, Australia: University of New England Publishing Unit.

Kennedy, P. M., Christopherson, R. J. \& Milligan, L. P. (1986). Digestive responses to cold. In Control of Digestion and Metabolism in Ruminants, pp. 285-306 [L. P. Milligan, W. L. Grovum and A. Dobson, editors]. Englewood Cliffs, NJ : Prentice-Hall.

Krebs, G. \& Leng, R. A. (1984). The effect of supplementation with molasses/urea blocks on ruminal digestion. Proceedings of the Australian Society of Animal Production 15, 704.

Krebs, G., Leng, R. A. \& Nolan, J. V. (1989). Effect on bacterial kinetics in the rumen of eliminating rumen protozoa or supplementing with soyabean meal or urea in sheep on a low protein fibrous feed. In The Roles of Protozoa and Fungi in Ruminant Digestion, pp. 199 -210 [J. V. Nolan, R. A. Leng and D. I. Demeyer, editors]. Armidale, Australia : Penambul Books.

Kronfeld, D. S. (1976). The potential importance of the proportions of glucogenic, lipogenic and aminogenic nutrients in regard to the health and productivity of dairy cows. Advances in Animal Physiology and Animal Nutrition 7, 5-26.

Kunju, P. J. G. (1986). Urea molasses block lick: a feed supplement for ruminants. In Rice Straw And Related Feeds In Ruminant Rations, pp. 261-274 [M. N. M. Ibrahim and J. B. Schiere, editors]. Wageningen: Pudoe.

Lee, G. J., Hennessy, D. W., Nolan, J. V. \& Leng, R. A. (1987). Responses to nitrogen and maize supplements by young cattle offered a low-quality pasture hay. Australian Journal of Agricultural Research 38, 195-207.

Leng, R. A. (1982). Modification of rumen fermentation. In Nutritional Limits to Animal Production from Pastures, pp. 427-453 [J. B. Hacker, editor]. Farnham Royal: Commonwealth Agricultural Bureaux.

Leng, R. A. (1989). Some factors influencing the efficiency of feed utilization by ruminants with special reference to the tropics. In Recent Advances in Animal Nutrition in Australia 1989, pp. 75-85 [D. J. Farrell, editor] University of New England, Armidale, Australia: Department of Biochemistry, Microbiology and Nutrition.

Leng, R. A. (1990). Recent advances in applied aspects of ruminant physiology and nutrition. Paper presented at VIIth International Symposium on Ruminant Physiology Sendai, Japan. (In the Press.)

Leng, R. A. \& Kunju, P. J. (1990). Development of feeding strategies for improving milk production in India from milch animals owned by small-farmers. In Proceedings from the Final Co-ordinated Meeting of 'The Use of Nuclear Techniques to Improve Domestic Buffalo Production in Asia' (1988). Vienna, Austria: International Atomic Energy Agency. (In the Press.)

Leng, R. A. \& Nolan, J. V. (1984). Nitrogen metabolism in the rumen. Journal of Dairy Science 67, $1072-1089$.

Leng, R. A., Nolan, J. V. \& Kempton, T. J. (1977). Non-protein nitrogen and bypass proteins in ruminant diets. Australian Meat Research Committee Review 33 (November), 1-21.

Lindsay, J. A. \& Loxton, I. D. (1981). Supplementation of tropical forage diets with protected proteins. In Recent Advances in Animal Nutrition in Australia, pl A Abstr. [D. J. Farrell, editor]. Armidale, Australia: University of New England Publishing Unit.

Lindsay, J. A., Mason, G.W. J. \& Toleman, M. A. (1982). Supplementation of pregnant cows with protected proteins when fed tropical forage diets. Proceedings of the Australian Society of Animal Production 14, 67-68.

McAllan, A. B., Cockburn, J. E., Williams, A. P. \& Smith, R. H. (1988). The degradation of different protein supplements in the rumen of steers and the effects of these supplements on carbohydrate digestion. British Journal of Nutrition 60, 669-682.

McAllan, A. B. \& Griffith, E. S. (1987). The effects of different sources of nitrogen supplementation on the digestion of fibre components in the rumen of steers. Animal Feed Science and Technology 17, 65-73.

McAllan, A. B. \& Smith, R. H. (1983). Factors influencing the digestion of dietary carbohydrates between the mouth and abomasum of steers. British Journal of Nutrition 50, 445-454.

McDowell, L., Conrad, J. H. \& Ellis, G. L. (1984). Mineral deficiencies and imbalances and their diagnosis. In Herbivore Nutrition in the Subtropics and Tropics, pp. 67-88 [F. M. C. Gilchrist and R. I. Mackie, editors]. Craighall, South Africa: The Science Press.

Maeng, W. J., Chang, M. B., Yun, H. S. \& Choi, I. (1989). Dilution rates on the efficiency of rumen microbial growth in continuous culture. Asian-Australasian Journal of Animal Science 2, 477-480.

Maeng, W. J., van Nevel, C. J., Baldwin, R. L. \& Morris, J. G. (1976). Rumen microbial growth rates and yields: effect of amino acids and protein. Journal of Dairy Science 59, 68-79.

Minson, D. L. (1982). Effects of chemical and physical composition of herbage eaten upon intake. In Nutritional Limits to Animal Production from Pastures, pp. 167-182 [J. B. Hacker, editor]. Farnham Royal: Commonwealth Agricultural Bureaux.

Ndlovu, L. R. \& Buchanan-Smith, J. G. (1985). Utilisation of poor quality roughages by sheep: effects of alfalfa supplementation on ruminal parameters, fiber digestion and rate of passage from the rumen. Canadian Journal of Animal Science 65, 693-703.

Nolan, J. V., Leng, R. A. \& Demeyer, D. I. (editors) (1989). The Roles of Protozoa and Fungi in Ruminant Digestion. Armidale, Australia: Penambul Books.

Orskov, E. R. (1970). Nitrogen utilization by the young ruminant. In Proceedings of the Fourth Nutrition Conference for Feed Manufacturers, pp. 20-35 [H. Swan and D. Lewis, editors]. London: J. and A. Churchill.

Orskov, E. R. \& Allen, D. M. (1966). Utilization of salts of volatile fatty acids by growing sheep. I. Acetate, propionate and butyrate as sources of energy for young growing lambs. British Journal of Nutrition 20, $295-305$. 
Orskov, E. R. \& Fraser, C. (1975). The effects of processing of barley-based supplements on rumen pH, rate of digestion and voluntary intake of dried grass in sheep. British Journal of Nutrition 34, 493-500.

Ørskov, E. R., Fraser, C., Mason, V. C. \& Mann, S. O. (1970). Influence of starch digestion in the large intestine of sheep on caecal fermentation, caecal microflora and faecal nitrogen excretion. British Journal of Nutrition 24 , 671- 682 .

Ørskov, E. R. \& McDonald, I. (1979). The estimation of protein degradability in the rumen from incubation measurements weighted according to rate of passage. Journal of Agricultural Science 92, 499-503.

Perdok, H. B. (1987). Ammoniated rice straw as a feed for growing cattle. PhD Thesis, University of New England, Armidale, Australia.

Perdok, H. B., Leng, R. A., Bird, S. H., Habib, G. \& Van Houtert, M. (1988). Improving livestock production from straw-based diets. In Increasing Small Ruminant Productivity in Semi-arid Areas, pp. 81-91 [E. F. Thomson and F. S. Thomson, editors]. Syria: International Center for Agricultural Research in Dry Areas.

Pethick, D. W. (1984). Energy metabolism in skeletal muscles. In Ruminant Physiology: Concepts and Consequences, pp. 277-287 [S. K. Baker, J. M. Gawthorne, J. B. Macintosh and D. B. Purser, editors]. Perth: University of Western Australia.

Pettipher, G. L. \& Latham, M. J. (1979). Characteristics of enzymes produced by Ruminococcus flavefaciens which degrade plant cell walls. Journal of General Microbiology 110, 21-27.

Pittman, K. A., Lakshmanan, S. \& Bryant, M. P. (1967). Oligopeptide uptake by Bacteroides ruminicola. Journal of Bacteriology 93, 1499-1508.

Preston, T. R. \& Leng, R. A. (1987). Matching Ruminant Production Systems With Available Resources In The Tropics And Subtropics. Armidale, Australia: Penambul Books.

Reis, P. J. \& Schinckel, P. G. (1961). Nitrogen utilization and wool production in sheep. Australian Journal of Agricultural Research 12, 335-352.

Romulo, B., Bird, S. H. \& Leng, R. A. (1989). Combined effects of defaunation and protein supplementation on intake, digestibility, $\mathrm{N}$ retention and fungi counts in sheep fed straw based diets. In The Roles of Protozoa and Fungi in Ruminant Digestion, pp. 285-288 [J. V. Nolan, R. A. Leng and D. I. Demeyer, editors]. Armidale, Australia: Penambul Books.

Russell, J. B. (1983). Fermentation of peptides by Bacteroides ruminicola B,4. Applied and Environmental Microbiology 45, 1566-1574.

Ryle, M. \& Orskov, E. R. (1987). Rumen ciliates and tropical feeds. World Animal Review No. 64, 2130.

Saadullah, M. (1984). Studies on utilization of rice straw by cattle. PhD Thesis, Royal Veterinary University, Copenhagen, Denmark.

Satter, L. D. \& Slyter, L. L. (1974). Effect of ammonia concentration on rumen microbial protein production in vitro. British Journal of Nutrition 32, 194-208.

Silva, A. T. \& Ørskov, E. R. (1988). The effect of five different supplements on the degradation of straw in sheep given untreated barley straw. Animal Feed Science and Technology 19, 289-298.

Silva, A. T., Greenhalgh, J. F. D. \& Ørskov, E. R. (1989). Influence of ammonia treatment and supplementation on the intake, digestibility and weight gain of sheep and cattle on barley straw diets. Animal Production 48 , 99-108.

Smith, R. H. (1984). Minerals and rumen function references. In Nuclear Techniques in Tropical Animal Diseases and Nutrition Disorders, pp. 79--96. Vienna, Austria: International Atomic Energy Agency.

Smith, R. H. (1989). Protein metabolism in the rumen. In Advanced Nutrition for Developing Countries, pp. 158177 [U. B. Singh, editor]. Ghaziabad, India: Indo-Vision Pvt Ltd.

Smith, R. H., Grantley-Smith, M. P., Merry, R. J., McAllan, A. B., Oldham, J. D. \& Salter, D. N. (1987). Supply of $\mathrm{N}$ compounds to the rumen and their subsequent metabolism and nutritional value. In Isotope Aided Studies on Non-Protein-Nitrogen on Agro-Industrial Byproducts Utilization by Ruminants, pp. 41-62. Vienna: IAEA.

Soetanto, H. (1986). Studies on the role of rumen anaerobic fungi and protozoa in fibre digestion. MRSc Thesis, University of New England, Armidale, Australia.

Sudana, I. B. \& Leng, R. A. (1986). Effects of supplementing a wheat straw diet with urea or a urea-molasses block and/or cottonseed meal on intake and liveweight change of lambs. Animal Feed Science and Technology $16,25-35$.

Suttle, N. F. (1987). The absorption, retention and function of minor nutrients. In The Nutrition of Herbivores, pp. 330-361 [J. B. Hacker and J. H. Ternouth, editors]. London: Academic Press.

Thonney, M. L., Touchberry, R. W., Boodrich, R. D. \& Meiske, J. C. (1976). Intraspecies relationship between fasting heat production and body weight: a re-evaluation of $W^{0.25}$. Journal of Animal Science 43, 692-704.

Ushida, K., Jouany, J. P., Kayouli, C. \& Demeyer, D. I. (1989). Effect of defaunation on fibre digestion in sheep fed $\mathrm{NH}_{3}$-treated straw based diets. In The Roles of Protozoa and Fungi in Ruminant Digestion, pp. 307-308 [J. V. Nolan, R. A. Leng and D. I. Demeyer, editors]. Armidale, Australia: Penambul Books.

Veira, D. M., Ivan, M. \& Jui, P. Y. (1983). Rumen ciliate protozoa: effects on digestion in the stomach of sheep. Journal of Dairy Science 66, 1015-1022.

Wanapat, M., Duangchan, S., Pongpairote, S., Anakewit, T. \& Tongpanung, P. (1986). Effects of various levels of concentrate fed with urea-treated rice straw for purebred American Brahman yearling cattle. In Ruminant Feeding Systems Utilizing Fibrous Agricultural Residues - 1985, pp. 149153 [R. M. Dixon, editor]. Canberra, Australia: Australian International Development Programme. 
Webster, A. J. F. (1989). Bioenergetics, bioengineering and growth. Animal Production 48, 249-269.

Wilson, J. R. \& Minson, D. J. (1980). Prospects for improving the digestibility and intake of tropical grasses. Tropical Grasslands 14, 253-259.

Young, B. A. (1983). Ruminant cold stress: effect on production. Journal of Animal Science 57, $1601-1607$. 